Macalester College

$$
\begin{gathered}
\text { Catalogue } \\
\text { I900-1901 }
\end{gathered}
$$




\section{In the Spring of 1883}

Before the Minnesota Loan and Investment Company was organized, GEo. D. DAYTON received word that a certain gentleman in New York City had deposited his "all," some thousands of dollars, to the credit of said Dayton, simply asking him to do the best he could with it. A few years later the owner of the money died, leaving everything to his widow. She at once turned everything over to the Minnesota Loan and Investment ('ompany to take care of for her, adding several thousand dollars received from her father. Three or four years ago she died, leaving ererything to her only son, who in turn asked the Minnesota Loan and Investment Company to take charge of the entire amount for him. At his request we have just arranged investments for each of his four children to run ten years. When these investments mature, we will have had charge of the funds for 28 years, and have served three generations.

\section{FIVE PER CENT. BONDS AT PAR.}

In amounts to sult investors, from $\$ 200$ up.

Interest payable semi-annually by draft on Now York.

Cholce real estate loans in a section that bas nerer known a crop fallure.

Send Drafts on New York, Boston, Philadelphia or Chicago.

\section{Minnesota Loan \& Investment Company,} Capital, $\$ 100,000.00$. Surplus, $\$ 100,000.00$. GEORGE D. DAYTON, President,

Worthington, Nobles Gounty,

Minnesota.

Interest always paid when due. No investor ever has to wait a day for his interest. 
SIXTEENTH ANNUAL

\title{
CATALOGUE
}

\author{
OF \\ Macalester College \\ AND
}

Classical Academy

I900-I90 I

SAINT PAUL, MINN

St. Paul, Minn.

WEBB PUBLISHING CO.

xgor. 


\section{Table of Contents}

Academy $\ldots \ldots \ldots \ldots \ldots \ldots 63 \quad$ Eutrophian $\ldots \ldots \ldots \ldots \ldots 15$

Administration $\ldots \ldots \ldots \ldots 17$ The Elms $\ldots \ldots \ldots \ldots \ldots 13$

Alunmni Association .....86 Historical Sketch ....... 8

Art .................. Laboratories ...........15

Athletics ..............21 Ladies' Accommdations ....13

Board of Trustees ....... 4 Library ..............16

Boarding ...............73 Location of College.......11

Books and Stationery.....23 Music ...............

Buildings .............11 Oratorical Association ....21

Business Department ......71 Pedagogy ..............47

Calendar ............. 3 Physical Culture $\ldots \ldots \ldots \ldots 21$

Commercial Studies .......71 Prize, Oratorical .........21

Curriculum Collegiate .....29 Reading Room ..........16

Academic ...........65 Religious Culture ........18

Deficiencies ............26 Reports .............22

Degrees $\ldots \ldots \ldots \ldots \ldots \ldots 23$ Requisites for Admission...26

Dormitory $\ldots \ldots \ldots \ldots \ldots \ldots 13$ Self-Support $\ldots \ldots \ldots \ldots \ldots 23$

Drawing ..............58 Societies $\ldots \ldots \ldots \ldots \ldots \ldots 20$

Elocution ..............56 Summer School .........58

Examinations ...........22 Text-Books-College ......61

Expenses .............. Academic ............72

Faculty $\ldots \ldots \ldots \ldots \ldots \ldots 4-63$ Tuition $\ldots \ldots \ldots \ldots \ldots \ldots .73$

General Information .......11 Typewriting $\ldots \ldots \ldots \ldots \ldots 71$

Gymnasium ............15 Woman's Auxiliary ......77

Halls: Edwards .........14 Y. M. C. A.............19

Dormitory $\ldots \ldots \ldots \ldots \ldots 13$ Y. W. C. A...............20 


\section{College Calendar.}

\section{1}

Spring Term opens

Senior Vacation begins.

Decoration Day.

Commencement of Academy.

Alumni Sermon by Rev. Archi-

bald Cardle, Slayton, Minn. .

Baccalaureate Sermon.

Annual Address beforethe $Y . M$. and $Y$. W. C. A.................

Field Day.

Class Evening.

Annual Meeling of the Board of Trustees in the President's Room

Business Meeting of Alumni Association.

Alumni Banquet.

Graduating Exercises of the Music Department

Twelfth Annual Commencement

Luncheon in the Gymnasium....

Entrance Examinations.

Fall Term opens with a Lecture in the College Chapel

Thanksgiving Recess.

Fall Term ends.
March 26, Tuesday, 10:00 A. M. May 11, Saturdav.

May 30, Thursday.

May 31, Friday, 8:00 P. M.

June 2, Sunday, 10:30 A. M.

June 2, Sunday, 3:00 P. M.

June 2, Sunday, 8:00 P. M.

June 3, Monday, 9:30 A. M.

June 3, Monday, 8:00 P. M.

June 4, Tuesday, 10:30 A. M.

June 4, Tuesday, 4:00 P. M.

June 4, Tuesday, 5:30 P. M.

June 4, Tuesday, 8:00 P. M.

June 5; Wednesday, 10:00 A. M. June 5, Wednesday, 12:30 P. M.

Sept. 10, Tuesday, 10:00 A. M.

Sept. 11, Wednesday, 10:30 A. M. Nov. 28, Thursday.

Dec. 20, Friday, 12:00 M.

\section{2}

Winter Term begins. Lecture... Jan. 8, Wednesday, 10:30 A. M.

Day of Prayer for Colleges...... Jan. 30, Thursday.

Washington's Bivthday............. Feb. 22, Saturday.

Winter Trm ends.... ............ March 28, Thursday, 12:00 M.

Spring Term begins............... Aprid 1, Tuesday, 10:30 A. M. 


\section{Board of Trustees.} Rev. R. L. BARACKMAN, - - - - Marshall, Minn. REv. T. H. Cleland, D. D., - - - - Duluth, Minn. GEO. D. DAYTON, - - - - Worthington, Minn. REV. F. W. FraSER, - $\quad$ - $\quad$ - $\quad$ - $\quad$ Crookston, Minn. REv. C. Harmon Johnson, - - - Willmar, Minn. PROF. ThOS. SHAW, - - - St. Anthony Park, Minn. Rev. Henry Schlosser, - - - - $\quad$ - St. Peter, Minn. EdWARd A. WEBB, - - - - - - St. Paul, Minn. Prof. B. F. Wright, - - - - - St. Paul, Minn. Terms expire June, 1901.

Rev. C. T Burnley, - $\quad$ - $\quad$ - $\quad$ - $\quad$ - Hudson, Wis. Judge R. N. Caruthers, - - - - $\quad$ - Grand Forks, N. D. W. H. DUNwoony, - $\quad$ - $\quad$ - $\quad$ - Minneapolis, Minn. REv. J. C. FARIES, - $\quad$ - $\quad$ - $\quad$ - Minneapolis, Minn. THOS. B. JANNEY, - $\quad-\quad$ - $\quad$ - Minneapolis, Minn. R. C. JEFFERSON, - $\quad$ - $\quad$ - $\quad$ - $\quad$ - $\quad$ - St. Paul, Minn.

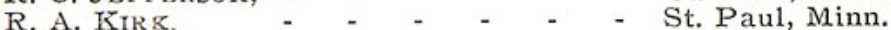
Charles E. Mackean, - - - - - St. Paul, Minn.

Terms expire June, 1902.

Rev. R. N. AdAMS, D. D., - - - Minneapolis, Minn. Rev. John E. Bushnelf, D. D., - Minneapolis, Minn. B. S. CoOK, - $\quad$ - $\quad$ - $\quad$ - $\quad$ - $\quad$ - $\quad$ Owatonna, Minn. Rev. Geo. W. Davis, Per. D., - - - - Mankato, Minn. J. A. Gordon, - - - - - $\quad$ - Minneapolis, Minn. Rev. Murdock McLeod, - - - - Merriam Park, Minn. Rev. A. B. Meldrun, D. D., - - - St. Paul, Minn. Henry L. Moss, - - - - - - St. Paul, Minn. JAMES WALlace, ex-officio, - - $\quad$ - St. Paul, Minn.

Terms expire June, 1903.

Fonorary Members.

Henry J. Horn, $\quad$ - $\quad$ - $\quad$ - $\quad$ - $\quad$ - St. Paul, Minn. Hon. Alexander Ramsey, - - - St. Paul, Minn.

0fificers of the Board.

Thos. Shaw,

R. A. KIRK,

B. F. WRIGHT,

C. E. Mackean, - $\quad$ - $\quad$ - $\quad$ - $\quad$ - $\quad$ - $\quad$ - Treasurer.

- $\quad$ - $\quad$ - $\quad$ - $\quad$ - $\quad$ - $\quad$ - President. Vice-President.

- Secretary. 
COMMITTEES OF THE BOARD.

R. A. KIRK.

MURDOCK MCLEOD.

Executive Committee.

Thos. SHAw, Chairman.

JAMES WALLACE. J. A. GORDON.

Finance Committee.

Geo. D. Dayton.

Thos. Shaw.

R. C. JEFFERSON.

Chas. E. Mackean. B. S. CoOK.

Committee on Endowment.

R. A. KIRK.

R. C. JeFFERSON.

JAMES WALLACE.

J. A. Gordon. GEO. D. DAYTON. ThOS. SHAW.

Committee on Instruction.

JAMES WALLACE, ex-officio.

J. C. FARIES.

JohN E. Bushnell.

B. F. WRIGHT.

E. A. Wевв.

Committee on Library

Geo. W. Davis

T. H. Cleland.

C. T. Burnley.

Committee on Buildings and Grounds.

Henry L. Moss. James TVallace. R. C. Jefferson.

SYNODICAL VISITORS.

Synod of Minnesota.

Rev. R. A. Montgomery, - - Presbytery, Duluth.

Rev. F. J. BARACkMAN, - - - Presbytery, Mankato.

Rev. C. H. Curtis, - - - Presbytery, Minneapolis.

REv. O. P. RIDER, - - - Presbytery, Red River.

Rev. C. Harmon Johnson, - - Presbytery, St. Cloud.

Rev. M. R. Paradis, - - - Presbytery, St. Paul.

Rev, J. Russell Jones, - - - - Presbytery, Winona.

Synod of North Dakota.

Rev. Edgar Willis Day, - $\quad$ - $\quad$ - $\quad$ - Eargo, N. D. 


\section{College Faculty.}

JAMES WALLACE, Ph. D., PREsment, Greek Literature, Political Economy.

EDWARD COLLINS DOWNING, A. M.,

Latin Lansuage and Literature,

ANDREW WORK ANDERSON, A. M., Mental Science, Logic and Philosophy.

REV. GEO. WILliam DAVIS, Ph. D., DEAN, 1

Biblica1 Studies, Hebrew, Sociology.

NEWTON KINGERY, A. B.,

Natural Sciences.

MRS. JULIA M. JOHNSON, A. M., DEAN OF THE WOMAN'S DEPARTMENT.

Rhetoric, English Literature and Old English

JOHN PORTER HALL, A. B., Greek Language and Greek History.

REV. HENRY D. FUNT,

German Language and Literature.

REV. W. J. JOHNSON,

Field Secretary, Pedargogics.

MISS ESTELLE FENNO, A. B., Assistant in Mathematics.

HARRY E. PHILLIPS, Piano and Voice Culture.

MISS GRACE B. WHITRIDGE.

Elocution.

MISS MARY KENNEDY,

Art.

ARTHUR O. BERGH.

Stringed Instruments, and Orchestra.

ANNA M. DICKSON,

Librarian.

REV. D. L. KIEHLE, PH. D.,

Course of Lectures on Pedagogy.

1 Abroad on leave of absence. 


\title{
OFFICERS AND COMMITTEES OF THE FACULTY.
}

\author{
Secretary. \\ EDWARD C. DOWNING. \\ Registrar. \\ NEWTON KINGERY.
}

On Buildings and Dormitory.

JAMES WALLACE.

w. J. JOHNSON.

JOHN P. HALL.

On Rules and Discipline.

JAMES WALLACE. JULIA M. JOHNSON.

E. C. DOWNING.

0n Gymnasium and Athletics.

NEWTON KINGERY. JOHN P. HALL. GRACE B. WHITRIDGE

On Public Exercises.

EDWARD C. DOWNING.

HARRY E. PHILLIPS

JULIA M. JOHNSON.

GRACE B. WHITRIDGE

Catalogue and Curriculum.

JAMES WALLACE.

HENRY D. FUNK.
ANDREW W. ANDERSON ESTELLE FENNO.

\section{0n Publications.}

EDWARD C. DOWNING. NEWTON KINGERY.

L. E. WHITNEY.

On Library.

ANDREW W. ANDERSON. JULIA M. JOHNSON. L. E. WHITNEY.

On Reading-Room.

JOHN P. HALL.

H. D. FUNK.

ESTELLE FENNO.

Other Officials.

Matron of Edwards Hall - - - - - MISS H. J. MOORE. MATRON OF EUTKOPHIAN HALL - - - - MRS. H. J. Elliot. MATRON OF THE ELMS - - - - - MRS. MARY CAMPBELL ENGINEER AND JANITOR - - - - - - - - A. W. FISHER. Assistant ENGINEer - - - - - - - - R. S. NUTT. 


\section{Historical Sketch.}

Macalester College is the outgrowth of the Baldwin school of St. Paul, projected by Rev. Edward D. Neill as far back as 1853, and of a similar institution opened in 1873 by the same gentleman in Minneapolis, near the Falls of St. Anthony. The former school received its name from Matthew W. Baldwin, of Philadelphia, a liberal contributor to its founding and support. The latter received its name from Charles Macalester, also of Philadelphia, who donated for its use a valuable property once known as the Winslow House, and located near the present Exposition building of Minneapolis. The institution, springing from the union of these two schools, was moved to its present site and opened in 1885.

Rev. Dr. Neill, the founder of the college, born in Philadelphia in 1823, graduated from Amherst in 1842, after completing his theological studies under Rev. Albert Barnes, came west, and in 1849, commissioned by the presbytery of Galena, Ill., he came to St. Paul as a missionary to the whites. Thereafter until his death (except during the civil war) he devoted his time about 
equally to the work of the Christian minister and to that of an educator. He was the first territorial superintendent of public instruction and the first chancellor of the state university. $\mathrm{He}$ is the author of Neill's History of Minnesota that has gone through several editions, and also of two volumes of valuable historical monographs. He died Sept. 26, 1893.

Next to Dr. Neill, in point of disinterested service for the college, stands Rev. Daniel Rice, D. D. Educated at Amherst College and at Andover Seminary, after long and useful service in Ohio and Indiana, he came to Mimnesota in 1875. The late years of his life (18791889) he devoted wholly and gratuitously to the upbuilding of this institution of which he was an honored trustee and professor.

Others most actively interested in the establishment of Macalester College were William C. Baker, Richard Chute, W. W. McNair, John S. Pillsbury, Judge C. E. Vanderburgh, Rev. J. C. Whitney, Hon. Eugene M. Wilson, Rev. Robert F. Sample, of Minneapolis, and Henry J. Horn, Henry M. Knox, H. L. Moss, ex-Governor Alexander Ramsey, Robert P. Lewis, H. K. Taylor, Thomas Cochran and Major B. F. Wright, of St. Paul. Later the college found warm friends and supporters in the persons of Rev. David James Burrell, D. D., and Rev. J. B. Donaldson, D. D., for several years president of the Board of. Trustees. A number of the trustees, like Drs. Neill and Rice, 
were honored sons of Eastern colleges, such as Amherst, Hamilton, Williams, Lafayette, University of New York, Union and others. The purpose, therefore, in the minds of these men was to build up in the Northwest an institution after the noble character and aims of these institutions whence they had come. This was their ideal.

Their successors on the Board have labored earnestly to realize this ideal. They seek to make Macalester College a center of culture and warm Christian influence- a school to which parents may confidently commit their sons and daughters, not only for thorough education, but also for the safeguarding and development of their character.

By a provision of the charter amended in 1885, twothirds of the trustees shall be members of the Presbyterian church. But in its instruction and internal administration the College is wholly non-sectarian and all its privileges are available to students of other faiths on equal terms. Students preparing for the ministry of any evangelical church receive tuition at half rates.

The college property includes seven buildings that have cost one hundred and eighteen thousand dollars, of which sixty-eight went into the main college building. The first class was graduated in June of 1889, since which ten other classes have followed. The alumni now number nearly one hundred. The corporate name of the institution is Trustees of Macalester College. 


\section{General Information.}

\section{Buildings and Grounds.}

Location.-Macalester College is located in Macalester Park, a beautiful suburb in the western part of the corporate limits of St. Paul, one-half mile south and a little east of Merriam Park. Its property fronts on Summit Avenue and is one mile south of the Interurban line where it crosses Snelling Avenue.

Campus.-The college campus contains thirty acres and is a beautiful piece of property. It has a frontage of six hundred and sixty feet on Summit Avenue, a fine boulevard two hundred feet in width, terminating one mile west on the banks of the Mississippi. The grounds contain a fine grove and efforts are making to beautify them in a manner befitting their surroundings.

Advantages of the Location.-The college is very pleasantly located. Macalester Park and neighborhood contains about thirty residences and is quite removed from the thickly settled parts of the city. The college is, therefore, away from the distractions and temptations of these cities. There are no saloons or other places of temptation in the vicinity. The location is favorable for study, for the development and 
maintenance of a pure and wholesome college life, and for careful supervision of the conduct of the students. Though the college is in a quiet and retired place, the students are brought in contact more or less with the life and culture of the city. The large public libraries, churches, lecture courses and musical entertainments are accessible and season tickets to the regular lecture courses are usually offered students at considerable reduction.

How to Reach the College.-The shortest route to the college is from St. Paul by way of Grand Avenue and Lafayette street car line to Snelling Avenue. The cars on this line run on Fifth street which is reached by going up Sibley street from the Union Depot two and one-half blocks. If the directions are forgotten, any policeman will give correct information as to how to reach the college.

The college is also easily reached from Minneapolis by way of the Interurban street cars, transferring at Merriam Park to the Selby Avenue line and leaving the cars at Snelling Avenue. A short walk of four blocks up Snelling brings one to the college grounds.

Persons with trunks or other heavy baggage should buy their tickets to St. Paul. On arrival at the depot, go direct to the college, leaving the baggageman to take care of the trunks. Arrangements are made at the college to have the trunks brought out at a small cost. Any student notifying the President or any Pro- 
fessor in time will be met on the arrival of any train at the depot.

1. College Building.-This is a brick building, one hundred feet long and fifty feet wide, three stories high, with large basement.

The first and second floors contain eight commodious classrooms and two well furnished society halls. The third floor contains an auditorium fifty by sixty-two feet, and a large room forty by fifty feet used for the Library and Reading Room.

The building is heated with steam and is provided with its own electric light plant.

2. Dormitory.-This also is a three-story brick building, ninety feet long by thirty-eight feet wide. The first floor contains the music studio, art room, Y. WV. C. A. room, mathematical room and physical laboratory. The second and third floors contain twenty double rooms designed, with sitting room and bedroom, to accommodate two students. They are furnished with plain, substantial furniture, are well lighted and thoroughly comfortable.

The building is heated with steam. Students must care for their own rooms or arrange with some one to do so.

3. The Elms.-This is an excellent frame building on the corner of Snelling and Summit Avenues, two blocks from the college, fitted up for the accommodation of young ladies. The location is very pleasant and 
the surroundings attractive. The rooms are spacious, furnished with single iron beds and other excellent furniture. Unless special arrangements are made, two students occupy the same room. The Dean of the women's department makes her home here, and every reasonable effort is put forth to make the Elms a pleasant, Christian home.

The general management of The Elms is under the care of the Woman's Auxiliary, an organization that seeks by active and earnest co-operation with Board and Faculty to promote the comfort and welfare of the young ladies. Mrs. Johnson, the Dean of the Woman's Department, makes her home here.

4. Edwards Hall.-This is a substantial three-story building on Macalester Avenue, one block south of the college. It is named after W. C. Edwards, Esq., of St. Paul, through whose generous liberality it was erected. It furnishes accommodations for twenty-two roomers, besides the matron and her help, and sets tables for forty. The plain, but excellent accommodations provided in this building and offered at very moderate rates have proved a great boon to students who find it difficult to meet the expenses of a college education. The students in this building form a club and manage the boarding department under a matron and other officers of their own choice, subject to the general supervision of the Faculty. The club has been admirably managed since the Hall was first opened. Room, 
board and laundry cost not to exceed two dollars and a half per week.

5. Eutrophian Hall.-This is a substantial brick building located on Grand Avenue, two blocks from the college. It has been rented for the use of students, accommodates about twenty roomers and has a dining room capacity for sixty or more. An excellent club has been conducted here, now under the capable management of R. L. Thompson, steward, and Mrs. H. J. Elliott, matron.

6. Chemical Laboratory.-The building erected originally for the library, through the liberality of Henry L. Moss, is now used as a chemical laboratory. It has desk room for twenty students, is thoroughly lighted and admirably adapted for laboratory purposes. It is well equipped with apparatus and offers facilities for both required and elective courses in chemistry.

Gymnasium.-The basement of the college building, a hundred feet long and fifty feet wide, with ceiling seventeen feet high, is used for a gymnasium. It contains a good lavatory supplied with hot and cold water, two hand-ball courts, ladders, hanging rings, horizontal bar and other apparatus. It is large enough to admit of basket ball practice and affords ample facilities for healthful athletic exercise. One dollar of each incidental fee is appropriated to athletics and physical training.

The Library.- The library contains about seven thou- 
sand volumes, not counting duplicates, most of it classified on the Dewey system. It is open every school day in the forenoon. It occupies a room forty-eight by fifty feet and affords excellent accommodations for both Library and Reading Room. Besides the college library, the students have access to the following public libraries:

St. Paul Public Library. . . . . . . . 45,000 volumes State Historical Library . . . . . . . . 63,000 volumes State Library . . . . . . . . . . 20,000 volumes Minneapolis Public Library.........106,000 volumes By the endorsement of a resident citizen any student may secure a card which will entitle him to draw books from the St. Paul Library.

The Public Library of St. Paul is situated on the corner of Seventh and Wabasha streets-but twentyfive minutes ride from the college on the Grand Avenue street cars. The State Historical Library and State Library are in the State Capitol and are also quite accessible from the college.

Reading Room.-An excellent reading room is maintained in connection with the Library. It is open during the morning and provides a pleasant place where students may profitably spend their vacant periods. It is furnished with a considerable number of the leading papers and magazines. 


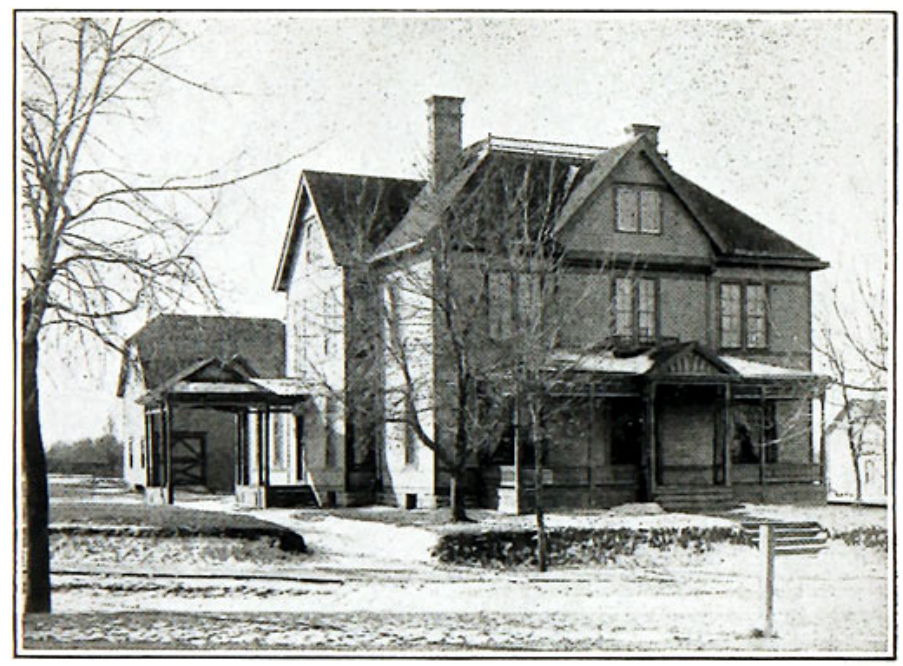

THE ELMS.

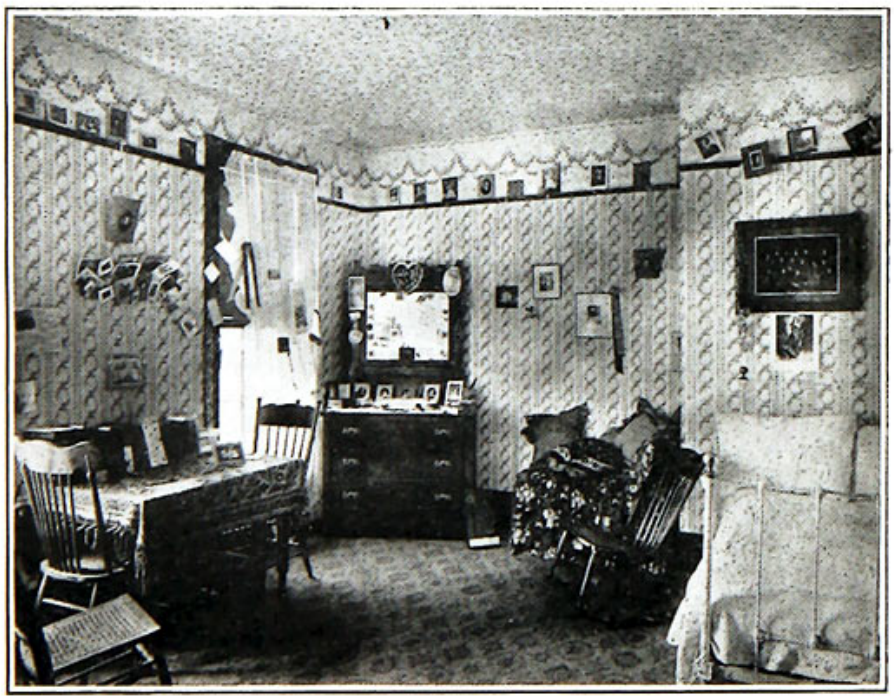

ROOM IN THE ELMS. 


\section{Administration.}

In the administration of the college appeal is made as far as possible to the self-respect and manliness of the students. They are constantly encouraged to guard well their honor and that of the institution, to maintain a wholesome esprit de corps.

Some regulations, however, are necessary, and when the students matriculate it is understood that they thereby submit themselves to the government of the college and pledge themselves to support the same while they are members of the institution. They are expected, and, by virtue of their matriculation as students of the institution, are understood to obligate themselves to act as ladies and gentlemen, to be faithful in attendance upon recitations, examinations, daily morning prayers, and Sunday morning service, and to be diligent in preparation of all tasks assigned.

Students of the Academy who are not of age may visit the cities only on Saturdays during the day or Sunday evenings to attend church. At other times permission must be obtained of the principal of the Academy.

College students are given greater liberty; but frequent visiting of the cities or returning late at night will be dealt with as offenses against good order.

Except in very special cases students are not permitted to room and board down in the city.

Students whose influence is found to be hurtful, 
even though guilty of no serious breaches of order, will not be retained in the institution.

\section{Religious Culture.}

Religious Services.-Devotional exercises are held in the college chapel daily at 10 a. m., at which all students are required to be present.

Public worship is held every Sabbath morning in Macalester Presbyterian Church. Attendance upon this service is required of all students except those boarding at home, and those excused by written request of parents or guardians to worship elsewhere.

The pastor of the church, Rev. J. M. MacInnis, takes a live interest in the spiritual welfare of the students and will welcome them at any time to his home for converse or advice in regard to personal religion. He conducts a class every Wednesday evening on the history of missions.

Young Men's Christian Association.-This association has an active membership of about forty members. It holds regular meetings every Tuesday evening and missionary meetings once a month. Several of the older members do home mission or Sunday school work in small churches located in the cities and within a reasonable distance of them. Going out to these country churches on Saturday evening they are usually 
able to return Monday morning in time for recitations. The association is in close touch with the associations of the two cities and finds opportunities of Christian activity and usefulness in the mission work of the cities. A committee of the association is present at the college two or three days before the College opens to meet and greet the new students as they come in. Members of this committee will meet any incoming student at the Union Depot, St. Paul, if notified beforehand of the time of arrival. Address Mr. Fred Brown, President.

Young Women's Christian Association.-This association, like the one above named, seeks to deepen the spiritual life of its members, to foster a Christian spirit in the institution, to bring its members into closer and more sympathetic touch with one another. Devotional meetings are held weekly in the Y. W. C. A. room and much attention is given to Bible study and to missionary themes. Any young woman who expects to enter the College is invited to write to the president or vice president of the association, telling when she will reach the city and she will be met at the depot. Any information about the institution will be gladly given upon inquiry. Address Miss Helen M. Wallace, President, or Miss Winifred Pringle, Vice President.

Society of Christian Endeavor.-A flourishing Endeavor society is held every Sunday evening in the local church of the Park. The society has proved an invaluable means of Christian culture. 


\section{Literary Societies.}

Three literary societies and one debating club are in operation under the general oversight of the Faculty. In the collegiate department there are the HyPerion, admitting to membership both young men and young women; the Philadelphinan, open to young men only; the Athamenear debating club for young men; and in the Academy, the Parthenon, open to all students of this department.

The Hyperion holds weekly meetings in its own handsome, well-furnished hall; the Philadelphian and Athenaean in the music studio, which has been nicely furnished in part at their expense.

It is expected and urged that every regular student will become connected with one or other of these societies and faithfully fulfil the duties of membership. No literary society or other organization may be established without consent of the Faculty.

Oratorical Association.-This association has about forty members and seeks to promote a live interest in Oratory. The interests of the College in the State Oratorical Association are under the control of this association. By means of a preliminary contest it selects one member to represent the College at the State oratorical contest. Hereafter the contestants will be chosen by the literary societies before the close of the college year preceding. 
Stringer Prize.-Through the kindness of Mr. E. C. Stringer, of St. Paul, the College is able to offer an annual prize of twenty-five dollars, to be given to that student of the College who, having not less than fourteen recitations a week, takes the first place in the preliminary oratorical contest mentioned above. At the contest held March 15 the prize was awarded to L. E. Hoy, Winthrop, S. D. The second place was won by Carl W. Jensen, Kasson, Minn.; the third, by Max Wiles, Yorktown, Iowa.

\section{Athletics.}

Athletics and careful physical training are encouraged and one dollar of each term's incidental fee is set apart for instruction in the care and training of the body and for the equipment of the gymnasium. A fine athletic field has been prepared, containing about five acres and lying just south of the College. There is ample room for lawn tennis and all the usual outdoor games.

As athletics can easily run into scandalous abuses the rules of the College require: 1 . That the teams of the College shall not play with colleges that admit professional members to their teams as is often done. 2 . That students who do not maintain a creditable standing in their classes shall not be permitted to become 
members in the College team. 3. That in match games with colleges outside of the cities the attendance from Macalester shall be strictly limited to the team proper and the necessary substitutes.

Foot-ball, though tolerated, is not encouraged. It is deemed. too rough, dangerous and exciting, particularly the intercollegiate games.

\section{Examinations and Reports.}

Examinations, written or oral, at the option of the professor, are held at the close of each term, and the class standing of each student is fixed according to his grades in class and on examination. The former usually counts two-thirds, the latter one-third. No student can retain class standing if the examinations are not taken. A record is kept of each student's grades in scholarship and deportment, a copy of which is sent to his parents or guardian at the end of each term. If these are not received the fact should be reported to the registrar.

\section{Degrees.}

Graduates from either the Ancient or Modern Classical courses receive the degrees of $\mathrm{A}$. B.; those from the Titerary course the degree of Lit. B.

This College has as yet granted no honorary degrees. 


\section{Books and Stationery.}

Books and Stationery may be purchased at the College at somewhat reduced rates. Text-books will be on sale at the opening of the term, and orders for books will be promptly filled.

\section{Self-Support.}

Students desiring to do something towards defraying their own expenses can usually find some way of doing so. Quite a number have found work in the past year, on the weekly holiday, in stores and other places of business, and have thus paid wholly or largely for their board. Others have earned their board by working mornings and evenings. It is seldom that any worthy, capable student fails to find some means by which he may work his way through College. Any student who earnestly desires an education, and can raise thirty or forty dollars, should feel encouraged to come and make a beginning. It is more than likely that the way will open for continuing his studies. 


\section{Collegiate Department.}

\section{COURSES OF STUDY.}

'This department embraces the following general courses:

I. The Ancient Classical Course, leading to the degree of A. B. In this course Latin and Greek are required to the end of the Sophomore year, after which modern languages or other branches may be chosen instead.

II. The Modern Classical Course, leading to the degree of A. B. In this course Latin and German are required to the end of the Sophomore year, after which these branches become elective.

III. The Literary Course, leading to the degree of Lit. B. The languages of this course are French and German, which are required to the end of the Sophomore year.

On entrance, the student makes choice of one of the above courses. Thereafter deviation from the course chosen must be by consent of the Faculty upon written application stating reasons.

In the Junior and Senior years elective courses are offered in the following subjects: Mathematics, Eng- 
lish Literature, Rhetoric (advanced) and Oratory, Hebrew, Greek, Latin, German, French, History and Political Economy, Civil Government, Natural Sciences, and Philosophy.

In the Sophomore year Pedagogy is offered instead of higher mathematics.

These general and elective courses of study, it is believed, are sufficiently broad to meet the ordinary wants of most students who are preparing to take up professional studies.

Partial Courses.-With the approval of the Faculty, students who are not looking forward to a degree, and who have sufficient preparation, are admitted to select courses. But in such cases a minimum of twelve hours a week will be required.

Admission from the Academy.-Graduates from Macalester Academy are admitted to the College course, for which they are prepared, without examination.

Admission from High Schools and Academies.-Grades and certificates from other colleges, from academies, and high schools will be accepted in lieu of examinations in so far as they represent an equivalent of preparation. Certificates from first-class high schools of Minnesota and Wisconsin will admit to the Freshman class subject to proper adjustment to courses herein offered. Certificates or grades from lower schools will be accepted, if creditable, for the work they represent. Verbal reports of standing will not be accepted. 
Students desiring to enter College without examination should send for an applicant's blank. This is to be carefully filled out and returned not later than September first. If this is done it will greatly expedite the work of classifying the new students at the opening in the fall.

Deficiencies.-Students who are not fully up to the requirements will be given every opportunity to remore their deficiencies, but no student should undertake to make up more than one-third of a year's work.

\section{REQUIREMENTS FOR ADMISSION TO THE FRESHMAN CLASS.}

Candidates for admission to the Freshman class must pass examination or present satisfactory credits in the following subjects:

\section{English:}

\section{Classical Course.}

Grammar, and Analysis, including Orthography, Punctuation.

Rhetoric and Composition.

Literature. This will include:

For careful study: Shakespeare's Macbeth; Mil- . ton's L'Allegro, Il Penseroso, Comus, and Lycidas; 
Burke's Speech on Conciliation with America; Macaulay's Essays on Addison and Milton.

For reading: George Eliot's Silas Marner; Pope's Translation of the Iliad (Books I, VI, XXII, and XXIV); The Sir Roger de Coverly Papers in the Spectator; Goldsmith's Vicar of Wakefield; Scott's Ivanhoe; Shakespeare's Merchant of Venice; Cooper's Last of the Mohicans; Tennyson's Princess; Coleridge's Rime of the Ancient Mariner.

No candidate will be accepted in English whose work is seriously defective in point of spelling, punctuation or grammar.

\section{Mathematics :}

Arithmetic: including the Metric System.

Algebra: Wentworth's, through Quadratics.

Geometry: Plane and Solid.

\section{Latin:}

Gramanar and Lessons (one year).

CAESAR: four books of the Gallic War.

SALLUST: Catiline.

VIrGIL: six books of the Aeneid.

Crcero: six Orations.

Prose Composition, based on Cæsar.

\section{Greek:}

Grammar and Lessons (one year).

XeNopion: four books of the Anabasis.

Prose Composition, based on the Anabasis. 


\section{Science:}

Grography: Modern and Ancient.

Physiology: Martin's Human Body, (elementary) or its equivalent.

Physical Geography: Tarr's, Davis', or their equivalent.

Elementary Physics: Carhart and Chute, or its equivalent.

VI. History:

United States: Johnston's, McMaster's, or their equivalent.

Greece: Oman's, Smith's, or their equivalent.

Rome: Myer's, Allan's or their equivalent.

England: Montgomery's, or its equivalent.

Modern Classical and Literary Courses.

Students wishing to take the Modern Classical or the Literary course will be examined or present credits in all of the foregoing subjects, except Greek, in lieu of which the following is required:

German :

Grammar and Lessons: Joynes-Meissner, or its equivalent.

READER: Joynes' Reader, or its equivalent.

Literature: Die Eiszungfrau, Doctor Luther, and Herman und Dorothea, or the equivalent of these.

Compositron: Simple prose.

Students deficient in Greek or German have excellent opportunity of making up their deficiencies in the Academy. 


\section{Synopsis of Courses of Study.}

\section{FRESHMAN YEAR.}

FIRST TERM.

ANCIENT CLASSICAL

*Greek, 4.

Latin, 4.

Mathematics, 4.

English, 3.

Oratory, 2.

Bible, 1.

Greek, 4.

Latin, 4.

Mathematics, 4.

English, 3.

Oratory, 2.

Bible, 1.

Greek, 4.

Latin, 4.

Mathematics, 4.

English, 3.

Oratory, 2.

Bible, 1.
MODERN CLASSICAL

German, 4.

Latin, 4.

Mathematics, 4.

English, 3.

Oratory, 2.

Bible, 1.

\section{SECOND TERM.}

German, 4.

Latin, 4.

Mathematics, 4.

English, 3.

Oratory, 2.

Bible, 1.

\section{THIRD TERM.}

German, 4.

Latin, 4.

Mathematics, 4.

English, 3.

Oratory, 2.

Bible, 1.
LITERARY

French, 4.

German, 4.

Mathematics, 4.

English, 3.

Oratory, 2.

Bible, 1.

French, 4.

German, 4.

Mathematics, 4.

English, 3.

Oratory, 2.

Bible, 1.

French, 4.

German, 4.

Mathematics, 4.

English, 3.

Oratory, 2.

Bible, 1. 


\section{SOPHOMORE YEAR.}

FIRST TERM.

ANCIEXT CLASSICAL

Greek, 3.

Latin, 3.

Mathematics Pedagogy

English, 3.

Chemistry, 3.

Oratory, 2.

Bible, 1.

Greek, 3.

Latin, 3.

Mathematics or Pedagogy

English, 3.

Chemistry, 3.

Oratory, 2.

Bible, 1.

Greek, 3.

Latin, 3.

Mathematics or Pedagogy

English, 3.

Chemistry, 3.

Oratory, 2.

Bible, 1.
MODERX CLASsICIL

German, 3.

Latin, 3.

$\left.\begin{array}{c}\text { Mathematics } \\ \text { or } \\ \text { Pedagogy }\end{array}\right\} 3$.

English, 3.

Chemistry, 3.

Oratory, 2.

Bible, 1.

SECOND TERM.

German, 3.

Latin, 3 .

Mathematics

or

Pedagogy

English, 3.

Chemistry, 3 .

Oratory, 2.

Bible, 1.

\section{THIRD TERM.}

German, 3 .

Latin, 3.

$\left.\begin{array}{c}\text { Mathematics } \\ \text { or } \\ \text { Pedagogy }\end{array}\right\} 3$

English, 3.

Chemistry, 3 .

Oratory, 2.

Bible, 1.
LITERARY

French, 3.

German, 3.

Mathematics $\left.\begin{array}{c}\text { or } \\ \text { Pedagogy }\end{array}\right\} 3$

English, 3.

Chemistry, 3 .

Oratory, 2.

Bible, 1.

French, 3.

German, 3.

Mathematics or Pedagogy

English, 3.

Chemistry, 3 .

Oratory, 2.

Bible, 1.

French, 3.

German, 3.

$\left.\begin{array}{c}\text { Mathematics } \\ \text { or } \\ \text { Pedagogy }\end{array}\right\} 3$.

English, 3.

Chemistry, 3.

Oratory, 2.

Bible, 1. 


\section{JUNIOR YEAR.}

\section{FIRST TERM.}

Required in all Courses.

1. English Literature, 3.

2. Physics, 3.
3. Logic, 3.

4. Political Economy, 2.

Elective in all Courses.

Rhetoric and Oratory, 2. Anal. Mechanics, 3. Chemistry, 3 .

Latin, 2.

Greek advanced, 3 . *Greek beginning, 5. German advanced, 3. *German beginning, 5 .
French advanced, 2.

French beginning, 4.

Hebrew, 2.

Pedagogy, 2.

Literary Study of Bible, 2. History of Philosophy, 3. Music advanced, 2. Greek Drama (through translations), 2.

\section{SECOND TERM.}

Required.

1. English Literature, 3.

2. Physics, 3.

3. Psychology, 3.

4. Political Economy, 2.

Elective.

French advanced, 2.

French beginning, 4 .

Hebrew, 2.

Pedagogy, 2.

Literary Study of Bible, 2.

History of Philosophy, 2.

Music advanced, 2.

Greek Drama, 2.

\section{THIRD TERM.}

Required.

1. English Literature, 2.

2. Physics, 3.

3. Psychology, 3.

4. Political Economy, 2.

Elective.

French advanced, 4 .

French beginning, 4.

Hebrew, 2.

Pedagogy, 2.

Literary Study of Bible, 2.

History of Philosophy, 2.

Music advanced, 2.

Greek Drama, 2.

German advanced, 3.

German beginning, 5 .

*Reckoned as an elective of three periods.

†Five or six periods weekly must be chosen. 


\section{SENIOR YEAR.}

FIRST TERM.

1. Astronomy, 3.

Required in all Courses.

2. Psychology, 3.

3. Sociology, 2.

4. Apologetics, 3 .

English Literature, 2.

Elective in all Courses.

Juniors), 2.

Calculus, 3.

Greek Anabasis, 5.

German advanced, 3.

German Reader, 5.

Philosophy, 3.

Political Science, 2.

French advanced, 3.

Literary Study of Bible, 2 . Hebrew, 2.

Latin, 2.

Music, 2.

SECOND TERM.

Required.

1. Astronomy, 3 .

2. Ethics, 3.
3. Geology, 2.

4. Constitutional History of the United States, 2.

English Literature, 2.

Elective.

Rhetoric and Oratory (with Juniors), 2.

Calculus, 3.

Philosophy, 3.

Political Science, 2.

Literary Study of Bible, 2.

Latin, 2.

1. Astronomy, 2.

2. Ethics, 3.
Greek advanced, 3.

Greek Anabasis, 5.

German advanced, 3.

German Reader, 5.

French advanced, 3.

French Reader, 4.

Hebrew, 2.

Music, 2.

THIRD TERM.

Required.

3. Geology, 5.

4. Constitutional History of the United States, 2.

Elective.

English Literature, 2.

Rhetoric and Oratory (with Juniors), 2.

Calculus, 3.

Philosophy, 3.

Political Science, 2.

Literary Study of Bible, 2.

Latin, 2.

Greek advanced, 3.

Greek Anabasis, 5.

German advanced, 3 .

German Reader, 5.

French advanced, 3 .

French Reader, 4.

Hebrew, 2.

Music, 2.

*Five or six periods week1y must be chosen. 


\section{Particular Description.}

\section{ENGLISH.}

I. Required-1. Rhetoric.-The course in Rhetoric for the Freshman class is intended (1) to cultivate the taste and develop the critical power of the student; and (2) to train him in accurate observation and thinking and to the use of clear, forcible, and elegant English. It includes the following:

1. A short course of lectures on the origin, dedevelopment, and characteristics of the English language, and a brief review of the principles of style;

2. A study in the essentials of logic;

3. Theory and practice in the making of abstracts and plans, and in the various kinds of prose writing, especially in exposition and argumentation;

4. Rhetorical studies in assigned literature.

Freshman year, three hours a week.

2. Anglo-Saxon.-Study of grammatical forms; reading of Sweet's Anglo-Saxon Primer and other selections. First term, three hours a week.

3. Middle English.-Sweet's First Middle English 
Primer with readings from Wiclif and Langland. Sophomore year. Second term, three hours a week.

4. American Literature.-The greater part of the work consists of readings and studies, under the direction of the Professor, in the lives and masterpieces of our great writers. Third term, three hours a week.

5. English Literature.-The aim of the course in the history of English Literature is to give a connected view of the main facts in the development of the literature by a study of three creative periods; the Chaucerian; the Elizabethan; the Classical; Chaucer, Spenser, Shakespeare and Milton are extensively read and discussed. Junior year, three hours a week.

II. Elective.-1. Elements of Literary Criticism.Senior year, first term is devoted to a study of models. Two hours a week.

2. From Milton to Tennyson.-A critical study of short selections. The aim of the course is to study the work of each poet in relation to his personal environment and the intellectual condition of the age. Senior year; second term, two hours a week.

3. A Study of Browning or Tennyson.-The choice will be made by the class. Senior year; third term, two hours a week.

4. Oratory.-This elective is open to Seniors and Juniors. Exposition and study of oratorical masterpieces, analysis of essays and arguments, themes and briefs. First and second terms, two hours a week. 


\section{MATHEMATICS.}

I. Required.-1. Higher Algebra.-A rapid review is made of simple equations, ratio and proportion, progression, and quadratics. Especial attention is given to indeterminate coefficients; development of binomial formula, logarithmic series and Taylor's formula. One term, four hours a week.

2. Trigonometry and Surveying.-Especial attention is given to definitions of trigonometric functions, development of formulae and their application to the solution of problems. In spherical trigonometry the principal formulae are developed and applied to the solution of triangles. In surveying the student is made familiar with the use of the transit and level and required to determine distances and areas. Two terms, four hours a week.

II. Elective.-1. Analytic Geometry.-A study is made of rectangular and polar co-ordinates; transformation of co-ordinates, development of the equations of the principal curves. The general equation of the second degree is discussed. Open to those who have completed Freshman work. One term, three hours a week.

2. Calculus.-One term is devoted to the differentiation of the various functions, expansion of functions, indeterminate forms, direction of curve, maxima and minima. One term is devoted to the development of the fundamental integral forms and their application to determining areas and rectification of plane curves. 
Open to those who have completed Differential Calculus. Two terms, three hours a week.

3. Analytic- and Hydro-Mechanics.-An application of Geometry and Calculus to Mechanics. Open to those who have completed Calculus. Three terms, three hours a week.

\section{LATIN.}

I. Required.-1. Freshman Year. Cicero and Livy. -Along with the reading of De Senectute and De Amicitia there is pursued a careful study of word-formation and phonology. The subject matter of Livy, together with the distinguishing characteristics of his style receive attention. Besides the reading of selections from Cicero's letters the social life of the Romans will be studied and discussed. Throughout the Freshman year there will be a constant application and elucidation of the principles of syntax. Three terms, four hours a week.

2. Sophomore Year. Horace and Tacitus.-While the grammar and metres of Horace will not be neglected, he will, nevertheless, be read as a poet, and his works will be studied as literature. Tacitus is regarded as presenting interesting facts in the Germania and Agricola, as possessing literary ability, and as a conspicuous example of the Latinity of his time. All these phases of the author are noticed. Three terms, three hours a week.

II. Elective.-Junior and Senior Years.-During 
these years Latin is an elective study twice a week. The following groups of studies may be pursued during the respective terms of either year.

1. Oratory.-(a) Cicero, De Oratore, (b) Cicero, Brutus or Oratio pro Milone, (c) Tacitus, Dialogus de Oratoribus.

2. Drama.-(a) Plautus, Aulularia, Rudens, (b) Plautus, Captivi, Trinummus, (c) Terence, Andria, Adelphoe.

3. Ethics.-(a) Cicero, De Finibus, (b) Cicero, De Officiis, (c) Seneca, Essays.

4. Lyric Poetry.-(a and b) Catullus, Tibullus, Propertius, (c) Latin Christian Hymns.

Each elective will receive the textual and collateral study appropriate.

Throughout the whole college course, students are cncouraged and expected to make original investigation, to formulate their own conclusions, and to cultivate the art of literary criticism. As much time as possible will be devoted to such collateral subjects as add both interest and information.

\section{GREEK.}

The Aim.-The general aim in this department is to learn to read Greek readily; to become acquainted with the Greek people as revealed in their great creations in history, oratory, philosophy, poetry and art; to arrive at a just estimate of the contribution of the Hellenic race to human progress. 
I. Required. Attic Greek.-The reading and study of easy Attic Prose, begun in the Academy, is continued through the first term of the Freshman year. Xenophon or Lucian are the authors read. Sight reading in the latter books of the Anabasis; reviews of grammar; composition (Jones) completed, one term, four hours a week.

Ionic Greek. (1) Herodotus.-Selections; study of forms; synopsis of his history (by Swayne, Ancient Classic Series). One term, four hours a week. (2. Homer.-Homeric accidence, syntax and prosody; structure of the Iliad; Homeric archaeology; influence on later epics; general summary of the contents of the Iliad and Odyssey (Collins, Ancient Classic Series.) Two terms, three hours a week.

Greek 0rators.-Selections from the orators. Rise, history and characteristics of Greek oratory; outlines of Demosthenes' orations (Brodribb). A part of the time may be devoted to the Greek histories (Thucyddes and Xenophon) at the option of the professor. One term, three hours a week.

II. Elective. Drama.-1. Aeschylus, Sophocles, Euripides, Aristophanes. Two or more plays in Greek; outlines of, and selections from, all the plays in English; studies in the Greek drama with helps, such as Haigh's Attic Theatre, Tragic Drama of the Greeks, Campbell's Greek Tragedy, Moulton's Ancient Classical Drama. Three terms, three hours a week. 
(2) Four 0ptions.-(a) The Greek Testament; the Acts of the Apostles and Epistles of St. Paul; rapid sight reading in the Gospels; mastery of vocabulary and study of N. T. Grammar. Three terms, three hours a week. Intended especially for candidates for the ministry.

(b.) Greek Philosophy, Plato and Aristotle.

(c.) The Lyric Poets.

(d.) Modern Greek.

There is usually more or less variation from the course laid down in Freshman and Sophomore years, to avoid routine.

\section{GERMAN.}

The Aim.-German is the distinguishing feature of the Modern Classical Course and runs parallel with the Greek of the Ancient Classical. The aim is to master the language both as spoken and written. The works of some of the best classical and living authors are read and the materials in the different books furnish the subject for easy conversation in German.

Composition and rapid reading of living authors is a feature of the advanced work.

I. Required.-Freshman year. The first term is devoted to Der Schwiegersohn by Baumbach and to ballads; the second to Freytag's Die Journalisten. The reading of these works is accompanied by exercises in composition and conversation. The third term is 
given to Braune Erica by Jensen. Four hours a week throughout the year.

Sophomore year. The following classics are critically read: Maria Stuart, by Schiller; Sessenheim, by Goethe; Minna von Barnhelm, by Lessing; Die Glocke, by Schiller; Der Fluch der Schoenheit, Der Stumme Ratsherr, Das Spelmannskind, by Riehl. Three hours a week.

II. Elective.-(1) Junior year. Those who continue German will read Ekkehard, by Scheffel; Haupt Fackta der Deutschen Litteratur, by Wilhelm Bernhardt; and Iphigenie, by Goethe.

Senior year. The literature read is Faust, Wallenstein, and selections from living authors. Three hours a week.

(2.) This elective is intended for those who have taken the Ancient Classical Course. The Junior year, first and second terms, are given to Grammar, Reader, Composition. The third term, to L'Arrabbiata, by Heyse. Four hours a week.

In the Senior year the following works are read: Immensee, by Storm; Eingeschneit, by Frommel, and Hermann and Dorothea, by Goethe. Three hours a week.

\section{FRENCH.}

I. Required.-In the Literary Course French is required through the Freshman and Sophomore years. Taken up after the three years of Latin required for 
entrance, rapid progress may be made in the mastery of the language. The first year is deroted to the elements, and easy reading; the second to French history and prose literature. Freshman year, four hours a week. Sophomore year, three hours a week.

II. Elective.-1. Open to students of the Literary course. The drama, fiction, history of the French literature. Junior and Senior years, each twice a week.

2. Open to students of the Ancient and Modern Classical courses. Junior year, same as in the Freshman Literary course. Senior year, same as in the Sophomore Literary course.

\section{HEBREW.}

Hebrew is elective in the Junior and Senior years. The course is intended, (1) to prepare students to do advanced work as soon as they enter the Seminary; (2) to enable them to specialize in some other department.

Junior Year.-The aim of this year's work is to master Genesis 1.-VIII., including:

(a.) The grammatical principles of the language.

(b.) Acquisition of the vocabulary.

(c.) Translation of the English into Hebrew.

Three terms, two hours a week.

Senior Year.-Critical study of one of the Minor Prophets, including text, grammar, exegesis and history. Three terms, two hours a week.

Opportunity will also be given for wider reading or 
readings at sight in the historical books in order to acquire greater facility in the use of the language.

\section{PHILOSOPHY.}

I. Required.-I. Logic and Scientific MethodThis course comprises a study of logic, deductive and inductive, of fallacies, logical theories, and of scientific method. Abundant exercises are given in order to fix the principles of the science in the minds of students, to cultivate the power of analysis, and to train to correct habits of thought and investigation. Required of all Juniors; 42 hours.

2. Psychology.-The aim of this course is a somewhat complete view of the most important parts of the science. Psychology, because of its essential relations to all other studies of this department and because of its value as a means of knowledge and culture, is given a large portion of time. Instruction, by means of recitations, informal lectures, experiments and discussions Three hours a week through the year.

3. Ethics.-The study of Ethics is put near the end of the curriculum in order that its philosophic aspects may be appreciated. The course, beginning with the history of ethical ideas and conceptions, proceeds with the psychology and philosophy of ethics, to the development of a theory of ethics and the application of this theory to life, political and social, family and individual. Two terms, three hours a week. 
II. Elective. Philosophy.-The course in Philosophy proper runs through the Junior and Senior years. Its aim is threefold; first, to show the nature and methods of philosophy, its reason for being, departments, and more important problems; secondly, to show the course of development and the present condition of philosophy; thirdly, to arouse a permanent interest in philosophical studies.

The following is a brief survey of the course, which will be varied from year to year. The time assignerl to the various subjects is only approximate:

1. History of Ancient and Mediæval Philosophy; readings in Plato and Aristotle. First term, thres hours a week.

2. History of Modern Philosophy through Kant. Special attention will be given to English philosophic thought and to Kant. Second term, three hours a week.

3. History of Philosophy since Kant, with reference to the course of thought at the present day. Third term, three hours a week.

The above courses are open to Juniors and Seniors.

4. Supplementary to the History of Philosophy a short series of lectures in defense of philosophy, and on its nature, departments and problems will be given.

5. All or nearly all of the second year of this course is given to a critical study of one or more of the great systems in their more interesting aspects, or to the study 
of the great problems as they are presented in the best current philosophical publications. Three hours a week through the year.

\section{POLITICAL SCIENCE.}

I. Political Economy. 1. Required.-A general survey is taken of the history, theories and generally accepted principles of Political Economy. Walker's textbook is used, supplemented by collateral studies, in Adam Smith, Mill, Ricardo, articles in cyclopedias, etc. Two hours a week through the year.

(2.) Elective.-In the elective course substantially the same ground is covered, but more attention is given to the historical development of the science, and to the application of sound principles to current economic questions. Two hours a week through the year.

2. Sociology.-Under this head is included the history, various theories and principles of Sociology. Important aims are, to show the extent of the field, to arouse an interest in the study, and to help to correct methods of sociological investigation. Wright's Practical Sociology is used as a text-book, but the systems of sociology as presented in Spencer, Ward, Giddings, Bascom, Henderson and others are presented and discussed. Two terms, two hours a week.

3. The Constitution of the United States. Required.This course contemplates three things: First, to trace the origin of the Constitution, and the causes which led to its adoption; secondly, to follow the development of 
constitutional theory and law; thirdly, to study and interpret the document itself. Hinsdale's text-book is used as a guide. Second and third terms of the Senior rear, two hours a week.

4. History of Civil Government.-The State, by Professor Wilson, is used as a text-book, with collateral study of constitutions. The aim is to trace clearly the great and distinctive features in the government of the leading European nations. Senior year, two hours in week.

\section{CHEMISTRY.}

I. Required. 1. General Inorganic Chemistry.-A careful study is made of some of the principal elements and their more important compounds, their occurrence in nature, preparation in laboratory, etc. Considerable time is devoted to the history and theories of the science, T'wo terms, six hours a week, counted in course as three.

2. Qualitative Analysis.-This includes the detection and separation of the principal metallic elements. Entirely laboratory work. One term, six hours a week.

II. Elective.-Advanced work in inorganic chemistry and analysis is offered to those who complete the required course.

The Chemical laboratory is well equipped for thorough work in the course offered. Especial attention will be given to scientific methods of observation and to interpretation of results. The work of both courses will be mainly in the laboratory. Each student will 
make a complete and systematic record of all his inrestigations. The aim will be to awaken the truly scientific spirit rather than to master a particular text. Three terms, three hours a week.

\section{PHYSICS.}

Required.-This includes a careful study of the various branches of the subject and involves a knowledge of Algebra, Geometry and Trigonometry. Much attention is given to the solution of problems. One term is devoted to mechanics of solids and fluids, and to heat; another to electricity and magnetism; a third to sound and light. The work is chiefly in the form of recitations and lectures, with a certain amount of laboratory work. Three terms, three hours a week.

\section{GEOLOGY.}

Required.-The method of study is by text-book and assigned topics.

In addition to the usual class-room work, students are expected to gather specimens, and, as far as time will permit, to make field excursions, so as to become familiar with our local geology. The Library contains the reports of the State Geologist of Minnesota and other valuable works on the subject. The college collection of specimens, though not large, is excellent. Two terms, three hours a week. 


\section{BIOLOGY.}

General Biology.-Elective.-A brief study is made of the morphology, physiology and development of various animal and plant forms. The time will be divided between recitations and laboratory work. The laboratory will, next year, be equipped with microscopes and all necessary supplies, each student having the use of a B. \& L. Compound Microscope with 2-3 and 1-6 in. objectives.

\section{ASTRONOMY.}

Required.-The time allotted to this branch is divided between mathematical and descriptive astronomy. Careful attention is given to the solution of the mathematical problems. Some time is given to the study of the heavens to enable the student to become acquainted with the names and positions of the principal constellations. Two terms, three hours a week.

\section{PEDAGOGY.}

Elective.-The course in pedagogy offers to those who look forward to teaching a comprehensive survey of the principles of their profession, and, to all, a study in the educational aspect of those principles which have characterized the conscious spiritual advancement of the race. The course comprises three divisions, each covering a year's work. 
1. History and Modern Systems of Education.-The general history of education, the history of education in the United States, and the educational systems of the leading European states are intended as introductory, leading to an understanding of the course of advancement and of our present position, as well as opening the vast treasure-house of educational thought and literature. Open to Sophomores, three hours a week.

2. Theory and Practice of Teaching.-In this division of the subject a study is offered of the problems of school management, mechanical aids to teaching, methods in general, and, finally, brief courses in the methods of teaching the important branches of elementary and secondary instruction. These last will be given in part by different members of the faculty in their own departments. Open to Juniors, three hour's a week.

3. Psychology and Philosophy of Education.-The course in psychology applied to education aims to dcvelop the psychological insight of the teacher and to fur. nish him with a correct basis of judgment and suggestion as a practical teacher. The course in the philosophy of education aims to reach some general conclusions as to the significance of human life and activity, and to develop a sense of the organized unity of education, its limits, ideals, values and of the plare of education in the general system of life.

It is recommended that students intencing to tike 


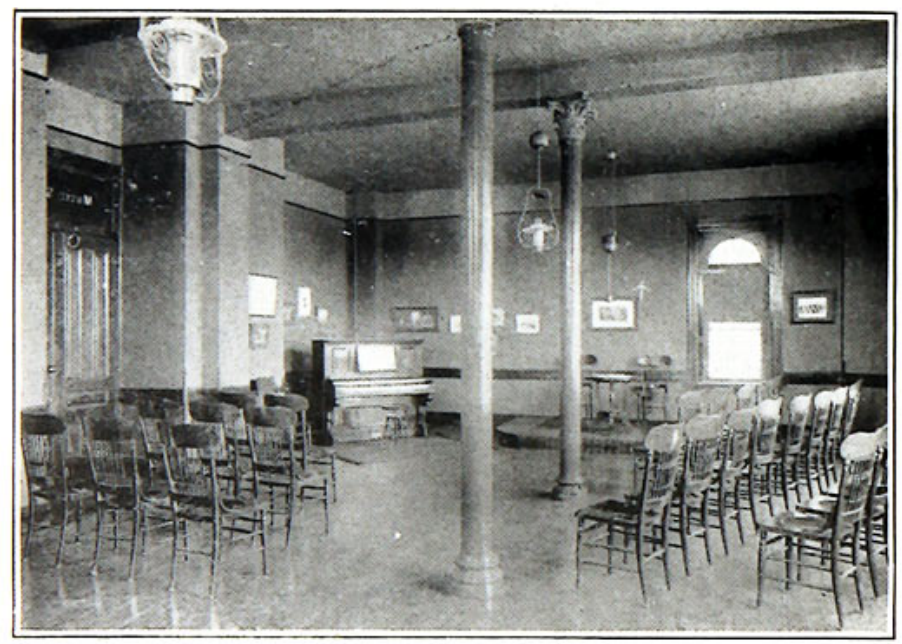

MUSIC STUDIO.

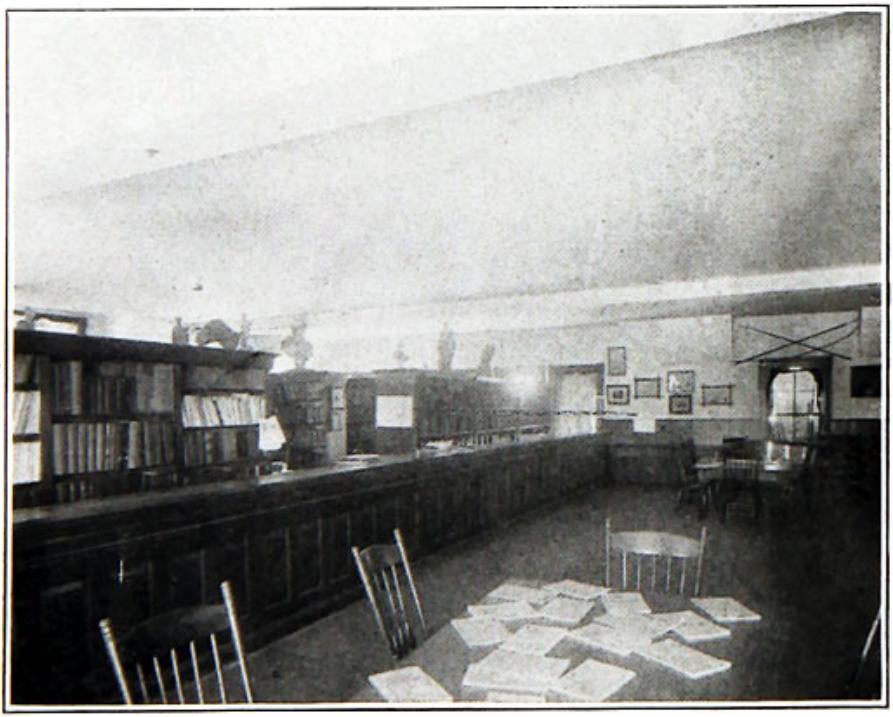

READING ROOM AND LIBRARY. 

this course should take first the elective in the history of philosophy. Open to Seniors, three hours a weck.

\section{BIBLE AND APOLOGETICS.}

The Bible has been given a prominent place in the college curriculum. It is deemed by the founders of the college to be the most important book in the whole range of literature; to furnish the most instructive biogra. phies and histories; to contain a literature both in prose and poetry of unrivaled excellence; to be the only revelation of a perfect law and of a perfect gospel, and to be one of the principal agencies in the development of true moral character.

The Aim.-It will be the aim of this department to aid the students in understanding and appreciating the manifold excellences that have secured for the Bible the title of Tre Book. The needs of those who are looking forward to evangelistic work, or engaged in it, are kept in view.

I. Required.-The Bible is a required study in the Freshman and Sophomore years.

1. 0ld Testament.-In this there is one recitation weekly throughout the Freshman year. The design is to (1) make the students fairly familiar with the leading events of Jewish history and with the salient religious teachings of the several books; (2) to study selected portions critically and inductively. Here a secondary object is to illustrate the inductive method of 
Bible study, its correctness and fruitfulness, and to quicken an interest in Biblical research.

2. New Testament. The Gospels.-This department of Biblical study embraces the preparation for Christianity, the life and teachings of Christ and the training of the Apostles. Sophomore year, one hour a week.

II. Elective.-In the Junior or Senior year twice a week: The subject offered is the literary study of the Bible with Dr. Moulton's text-book for a guide and the literary and exegetical study of some master-pieces, as Isaiah, Job, and some of the Psalms.

[For the courses in Hebrew and New Testament Greek, see Curriculum of the Junior and Senior years.]

Apologetics.-(1) This course aims chiefly at two things:

First, a brief exposition of Christian theism and an exhibition of its superiority in philosophy and in practice to the various opposing theories; deism, pantheism, materialism and agnosticism.

Secondly, a summary of the argument for historical Christianity and an examination of criticisms and objections, especially those of our own day. Required, fall term three hours a week. 


\section{Music.}

The students of music are under the instruction of Prof. Phillips, of St. Paul. Mr. Phillips has had the advantage of thorough training both at home and abroad. He spent four years of study in Stuttgart, Germany, under Prof. Speidel (piano), Breed (voice), Faisst (organ) and Goetschius (harmony).

Since his return in 1889 he has been successfully engnged in the teaching of music in the city of St. Paul, and has been prominently identified as a baritone and director of music with various important churches of the city, namely: Dayton Avenue Presbyterian, St. Luke's Catholic, People's Church, Jewish Synagogue.

The Place of Music.-Music has been viewed too much as a mere accomplishment. It has come to be recognized, rather, as having high educational value and as constituting an important part of a complete education.

Music as an Elective.-To encourage the more thorough study of music, it is proposed to permit students to take advanced work in music, in the Junior and Senior years, subject to the approval of the Faculty, in lieu of some other elective.

The Course of Study pursued embraces the following branches: 
Piano-forte, vocal culture and singing, organ, violin and other stringed instruments, harmony, counter-point, and general musical theory.

Piano.-It is the aim of this department to make thorough pianists. Modern science has accomplished much in the study of the arm, wrist, knuckles and fingers, involving many new motions and combinations for controlling touch and technique much in advance of ordinary methods. Much disappointment and misdirected effort can be spared by proper attention to these details at the outset. Pupils are simultaneously taught and are expected to study harmony, musical analysis, and the correct reading of all signs of expression, phrasing, dynamic values, touch, proper use of the damper pedal, etc.

The course has been divided into three years, with a post-graduate course of one year.

First Year.-Mason's Touch and Technique; Douvenoy, Op. 120; Lorschorn, Op. 65; Czerny, Fingerfertigkeit; Bach, two-part inventions; easy sonatinas by Haydn, Mozart, Clementi and Duesck.

Second Year-Bertini, Op. 29; Heller, Op. 45; Cramer, 50 studies, or Clementi's Gradus; Kulak, octave studies; sonatas by Mozart, Beethoven; Mendelssohn's Songs without Words; Chopin's mazurkas, nocturnes, etc.

Third Year-Heller's Art of Phrasing; Bach, preludes and fugues; a few of the Chopin studies; and the 
more difficult sonatas of Beethoven; selections from Chopin, Mendelssohn, Weber, Schumann, Schubert and others.

Post-Graduate Course.-The more difficult Chopin studies; Bach, organ preludes and fugues, arranged for piano; concertos, and the more difficult selections, Beethoven, Mendelssohn, Chopin, Rubenstein and Henselt.

Voice Culture.-In the department of vocal music, those methods which experience justifies as being at once effective and artistic in their results, have been adopted. It is the policy to secure a systematic and thorough culture on the basis of the best Italian methods. All students are expected to pursue a course of theoretical study to perfect themselves in sight-reading and in all essential and practical details of the art, which are sometimes neglected in behalf of superficial and showy features.

Forward, high-placing and deep resonance of tone, is the true basis of voice work, special attention being paid to the breathing exercises.

The celebrated methods of Dellesedi, Shakespeare, and others are used; also Vocalisses, Concone, Veccoj and Marschesi ; songs by Lassen, Grieg, Bach, Gounod, Schubert, Mendelssohn, Wagner and others.

The Organ.-The course of study on this instrument will include Rinck's Organ School, Buck's Pedal Studies, Bach's Preludes and Fugues, Mendelssohn's Sonatas. Registration, and playing of church music will 
receive special attention. Students have access to a fine two-manualed pipe-organ.

The study of harmony, counter-point, etc., is obligatory on the part of those who receive certificates or diplomas. Certificates will be awarded at the close of the first and second years, and a diploma at the close of the third year, to pupils who pass the regular examinations in their respective classes.

Sight Reading.-Classes free for those who wish to take up the work.

History of Music.-In the study of the history of music Mathews' Popular History of Music and Fillmore's Lessons in Musical History will be used. Students will also have access to other authorities.

Satisfactory provisions will be made for any who wish to take lessons on the violin or other string instruments.

Monthly recitals in both vocal and instrumental music will be given, in which all musical students will be required to participate. Monthly lecture recitals by Prof. Phillips and others in both vocal and instrumental music will be given throughout the year.

A choral club, as well as a glee club, has been carried on very successfully, and will be continued. The best choruses of church and secular music will be studied, as well as the college songs, which are so dear to the memory of both young and old. 
The Study of Church Music.-For students who desire special training in church music, appropriate courses will be carried out. The wide experience of Prof. Phillips in such music fits him peculiarly for this work.

Violin.-Instruction on the violin is given by Prof. Arthur O. Bergh, of St. Paul, one of the most competent teachers in the city.

Terms.-Piano, Voice, Organ:

Fall term, two lessons a week...........\$25.00 Fall term, one lesson a week........... 14.00 Winter term, two lessons a week. ......... 21.00 Winter term, one lesson a week........... 12.00 Spring term, two lessons a week.......... 11.00 Spring term, one lesson a week.......... 10.00 Rent of piano for practice, per term, one hour a

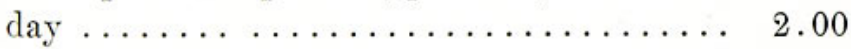

Harmony will be taught in classes at a nominal price.

Students in music should set aside a certain sum each term for the purpose of hearing the best musical talent in vocal, piano, and orchestral concerts that comes to the city.

Music students are permitted to take one study in College or Academy of two or three hours a week without extra charge.

Music, instrumental or vocal, may be taken as an elective in the Junior and Senior year, provided the student is sufficiently proficient to do advanced work. A minimum of not less than six hours a week must be 
devoted to the study and it will not be acepted for more than two periods or credits per week. The fitness of the student to take this elective will be determined by examination, and the expense of the instruction must be borne by the student.

\section{Elocution.}

The department is under the direction of Miss Grace Whitridge, a post-graduate of the Boston School of Oratory, and a pupil of Mr. F. F. Mackay, director of the National Dramatic Conservatory of New York.

1. Method.-The system of training is based upon the principles taught at the Conservatoire in Paris.

"Every art must have an underlying science. Creation is the exponent of supreme power and wisdom. Art is the exponent of all human power and knowledge. Science is systematized knowledge. Elocutios: is both a science and an art. As a science it recognizes emotion, dissects it, arranges it and presents for study the factors which produce it. As an art it puts into practice the appropriate, natural and artificial means by which emotion can be expressed. This being understood, the student of acting or of elocution is taught that emotion is the expression of a sensation aroused by some external circumstance, and he is made to analyze and 
represent the physical effects which the various cmotions in nature produce, and the natural language by which they express themselves."

2. The aim of the work is to teach the students scientific principles and to give them artistic and practical training which will enable them to avoid all aftectation and rant, all mere trickery and striving for effect. Every pupil must pass a prescribed percentage to entitle him or her to a public appearanice. It is hoped the value of this department will be felt by all our students, whether preparing for public or private work, and that such vigor and earnestness noy eiter therein as to give it a place among the elective subjects.

3. Outline of Study-

1. Breathing, Voice Production-Theory, practice.

Science and art of elocution in its relation to reading, recitation and oratory-Factors of expression.

2. Analysis of Emotions-Theory, practice. Physical Training-Pose, gesture, facial expression.

Analysis and rehearsing of one Shakespearean play.

Bible reading.

Required.-Elocution is required in the Freshman and Sophomore year classes. Students taking Elocution will be required to pass examinations as in the case of other studies. 


\section{Art.}

During the year a room has been fitted up for instruction in Art. The branches of study are drawing from the antique (busts, models, etc.), crayon and color work. The department is under the direction of Miss Mary Kennedy, formerly of Oberlin.

\section{Summer School.}

With the approval of the Board of Trustees the Faculty has decided to open a Summer School. It will continue eight weeks, beginning June 17 and closing August 9.

\section{The Object:}

The object of the school is:

1. To enable students to make up deficiencies preparatory to entering Freshman or other classes in the fall.

2. To enable teachers whose education has been interrupted to prosecute their studies with a view to graduation from college. An increasingly large per cent of the public school positions are open only to college and university graduates. It is believed that 
many public school teachers will eagerly embrace the opportunity offered in the summer school to prosecute their college studies at small cost.

\section{Classes:}

Classes will be formed in:

Algebra, School and Higher; Geometry, and (if there is a sufficient demand) in higher branches. Latrix: Lessons, Cresar, Cicero, Vergil and other authors, if there is sufficient demand for them.

Greek: Lessons, Anabasis, Homer, etc.

German: Beginning and higher classes.

ENGLISH: Rhetoric and Literature.

Chemistry and Physics: Elementary.

Mussc: Piano, Violin, Voice, and certain other studies if there is sufficient demand for them.

Commercial Studies.-Instruction will also be given in Commercial Arithmetic; Commercial Law, Typewriting, Stenography, etc.

Instruction.-The instruction will be given by some of the regular professors assisted by competent instructors.

Location and Environment.-Macalester Park is a pleasant place to spend the summer. There are pleasant groves in the vicinity. The college grounds face on Summit Avenue-famed for its beauty. It is a short distance by wheel to Como Park, one of the most beautiful parks in the Northwest, and offering sundry musical attractions in the evening. The beau- 
tiful banks of the Mississippi are but a mile and a haii to the west. The interurban bicycle-path passes in front of the college property. Minnehaha Falls and Fort Snelling are interesting points for short excursions on the wheel.

The Terms:

Tuition ................ \$12.00

Board, per week............. 3.00

Room rent (per week)-

Dormitory $\ldots \ldots \ldots \ldots \ldots \ldots . \quad .50$

Corner rooms........... $\quad .75$

The Elms (Ladies' Hall)..... $\quad .75$

Edwards Hall............ .25

It is desirable that application for rooms should be made early, as they will be assigned in order of application.

For further information address Prof. Edward C. Downing, Macalester Park. 


\section{COLLEGE TEXT-B00KS.}

English.-(Genung's) Elements of Rhetoric; Sweet's Anglo-Saxon Primer and First Middle English Primer, Brook's Primer of English Literature with full text of Chaucer, Spenser, Shakespeare, and Milton. From Milton to Tennyson by Syle. Elements of Criticism by Johnson. Exposition of the Sentence and Paragraph by Baldwin. Select Essays of Addison by Thurber. Orations and Arguments by Bradley.

Mathematics.-Olney's University Algebra. Wentworth's Plane and Spherical Trigonometry and Surveying. Nicholl's Analytic Geometry. Osborne's Differential and Integral Calculus. Bower's Analytic Mechanics.

Latin.-Harkness' Grammar. Mather \& Wheeler's Prose Composition. Harper's Latin Dictionary. Any standard edition of the authors.

Greek.-Liddell and Scott's Intermediate Greek Lexicon. Hadley-Allen's Grammar with Goodwin for reference. Any standard edition of the texts, as Mather's Herodotus, William's Lucian, Seymour's or Keep's Tliad, Tyler's Demosthenes, Wagner's or Dyer's Plato's Apology, etc. Haigh's The Attic Theatre and The Tragic Drama of the Greeks, Campbell's Greek Trag. edy.

German.-Joynes-Meissner's Grammar. Joynes' Reader. Koehler and Lambeck's Dictionary recommended. Standard editions of the authors, as Thiomas' Faust, Stern's Geschichten von Rhein, Brenhart's Immensee.

French.-Edgren's Grammar. Whitney's Introductory French Reader. Benton's Easy French Plays. 
Joynes' Classic French Plays. Spier and Surienne's French Dictionary.

Hebrew. - Harper's Inductive Method. Davies' Complete Hebrew and Chaldean Lexicon.

Philosophy.-Logic: Hyslop's Elements; for reference Mill, Jevons, Hamilton, Venn, Sigwart.

Psychology.-James' Principles; for reference Baldwin, Ladd, Hoeffding, Sully.

Ethics.-Paulsen's System of Ethics; for reference Green, Martineau, Sidgwick, Porter.

Philosophy.-Fistory of, Weber; James' The Will to Beliere, Microcosmus by Lotze.

Political Science.-Political Economy by Walker; for reference and outlines, Mill, Ricardo, Adam Smith, De Li. veleve, Gide and others.

Sociology.-Wright's Practical Sociology; for reference and outlines, Spencer, Ward, Giddings, Bascom, Henderson and others.

History of Civil Government.-Wilson's The State, Constitutions edited by F. A. Cleveland. Constitution of the Tnited States by Hinsdale.

Chemistry.-Newth's Inorganic Chemistry. Noyes' Qualitative Analysis.

Physics.-Hastings and Beach.

Geology.-Carhart with Dana's large work and others for reference.

Botany.-Coulter's works.

Astronomy.-Young.

Bible.-Revised Version. Stevens and Burton's Harmony of the Gospels with notes. Wescott and Hort's Greek Testament. Moulton's Literary Study of the Bible. Cambridge's Bible for Schools, select volumes as on Isaiah and Job. Bruce's Apologetics. 


\section{The Academy.}

\section{Faculty.}

JAmes WALlace, President of Colleige.

EDWARD C. DOWNING, A. M., PRINCIPAL.

Latin and Roman History.

NEWTON KINGERY, A. B.

Science.

JULIA M. JOHNSON, A. M.

English and History.

JOHN P. HALL, A. B.

Greek and Greek History.

REV, HENRY D. FUNK,

German.

REV. CHAS. SCANLON, B. S.

Bible and Junior Brunches.

LLOYD E. WHITNEY, Business Studies.

MISS ESTELLE FENNO, A. B. Mathematics.

MISS A, M. DICKSON, A. B. Latin and Greek.

A. B. MCCALLISTER, Latin. 


\section{Admission and Courses.}

The purpose of the Academy is to prepare thoroughly for the standard courses in any college, to provide a good general education for those who cannot carry their studies further.

The languages of the Ancient Classical are Latin and Greek; of the Modern Classical and Literary, German and French. The Scientific substitutes Science for a part of the Latin of the other courses.

Besides the above, a course including Commercial Studies is offered. In this course, commercial studies, such as Commercial Arithmetic and Geography, Commercial Law, Business Correspondence, Stenography and Typewriting, etc., are substituted for the Latin and German of the Scientific.

General Conditions of Admission. These are the same as for the College. See page 25.

Requirements for Entrance. All applicants for admission to the first year class are examined in Orthography, Elementary English and Arithmetic (through factor. ing), Descriptive Geography, and United States History. Applicants for admission to higher clases will, in addition to the above, be examined in the studies of the classes below that for which they apply. Certificates are accepted in lieu of examinations in so far as they represent equivalents in time and in work of studies prescribed in the Academic course. 


\section{SYNOPSIS OF ACADEMIC COURSES OF STUDY.}

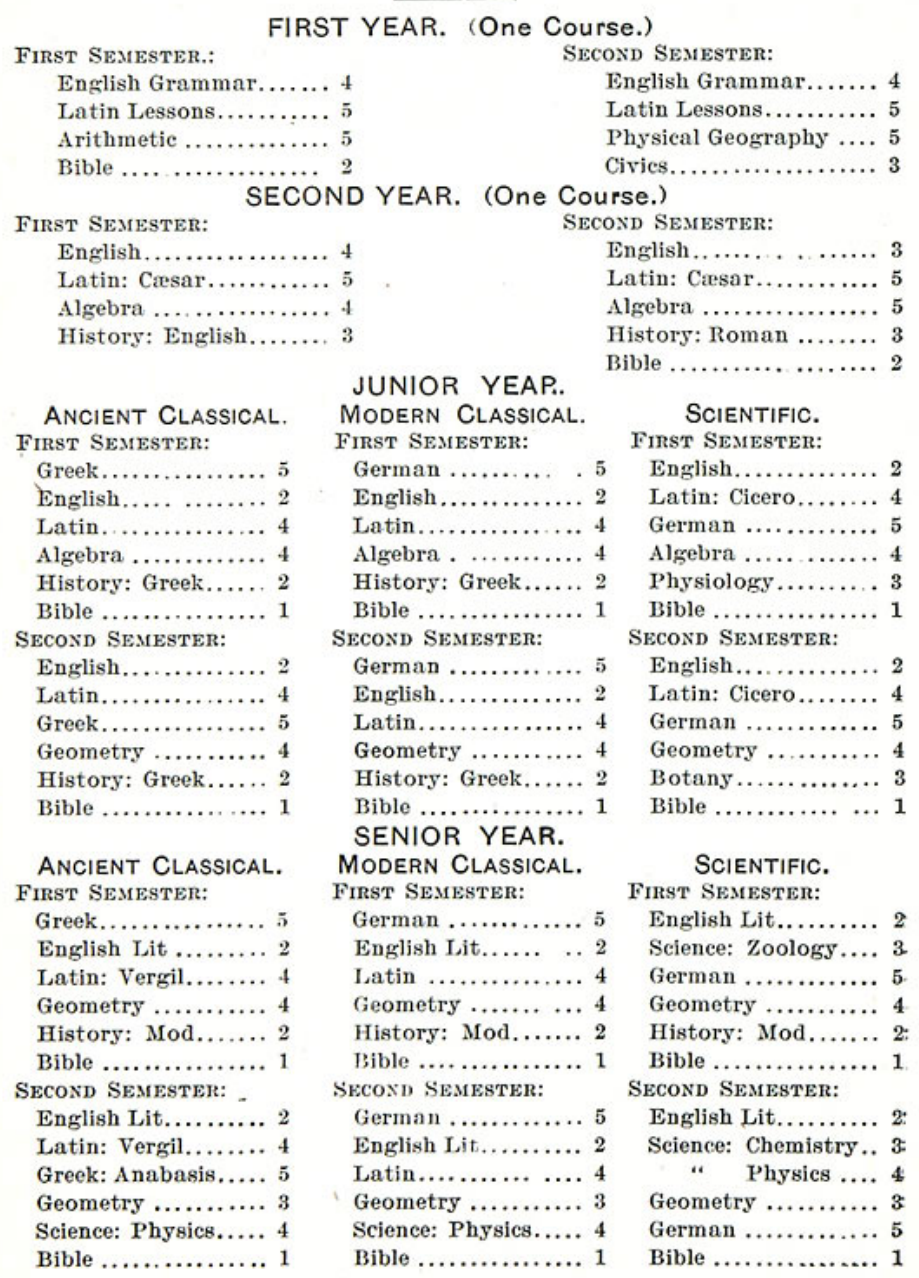




\section{Particular Description.}

\section{ENGLISH.}

The Academic course in English prepares for college entrence and at the same time offers a course somewhat complete in itself.

1. First Year. The first year is devoted to the study of grammar, sentence analysis and composition, including punctuation, capitalization, etc. Three terms, four hours a week.

2. Second Year. In the second year the text used is Genung's Outlines of Rhetoric. Special emphasis is placed upon the study of words, figures of speech, elements of sentence and paragraph structure. Models from the required list of authors are studied. As a means of gaining facility, precision and force of expression, students are required to prepare one or more short themes weekly. Three terms, four hours a week.

3. Third Year. During this year composition is continued, with analysis of masterpieces in the uniform admission requirements. Training in discussion and debate. Two hours throughout the year.

4. Senior Year. In the Senior year Painter's Introduction to English Literature is the text-book. Subjects for composition are taken from the required reading. Much attention is paid to the application 
of sound principles of criticism to the literature read. Three terms, two hours a week.

For the literature to be read before entering the Freshman Class, see English required for entrance.

\section{MIATHEMATICS.}

The course in Mathematics includes Arithmetic, Algebra, and Geometry.

1. Arithmetic is studied throughout the first year. Great familiarity with the elementary principles is required, and abundant practice in the solution of problems is given. Those who take the Business course will have special instruction in Commercial Arithmetic.

2. Elementary Algebra is taken up at the beginning of the second year and is continued throughout the year, reciting four times a week. The aim is to ground the student thoroughly in the fundamental operations of Algebra which lies at the basis of the Mathematical course.

3. Advanced Algebra. The work of the third year in Mathematics carries the student through quadratic equations.

4. Geometry is studied throughout the Senior year, and both plain and solid geometry are completed. Students are required not only to master the text-book, but also to solve numerous original problems and theorems. Four hours a week. 


\section{LATIN.}

Latin is a required study in each of the Academic courses. During this time the student is expected to acquire a large vocabulary, a wide knowledge of the rules of syntax, and the ability to convert English into the Latin idiom. These things furnish an indispensable basis for the work pursued in the College classes. Special attention is given to the forms and structure of the language, which are studied by severe methods of both analysis and synthesis. The grammar is thoroughly studied, and the memory is helped by a rational explanation of forms.

1. Latin Lessons. The FirstYear is spent in the study of the declensions and conjugations, syntax and vocabulary, in making translations daily to and from the Latin, and in conversation. Five hours a week.

2. Caesar and Composition. The Second Year is devoted to careful and thorough study of Cæsar, Nepos and composition. Five hours a week.

3. Cicero and Composition. The Third Year is devoted to Cicero, composition, and a more thorough study of the Grammar. Four hours a week.

4. Vergil. The Senior Year is devoted to Vergil. The Aeneid is studied both textually and as literature. Four hours a week.

\section{GREEK.}

Greek is a required study in the Ancient Classical course. 
1. Lessons. The aim of the first year's study of Greek is to master the elements, six hundred to eight hundred carefully selected Greek words, and two or more chapters of the Anabasis. The method followed, after the more important paradigms are mastered, is in the main inductive. Five hours a week.

2. Anabasis and Composition. In this year an effort is made to read thoroughly four books of the Anabasis. The reading is accompanied with prose exercises and sight-reading in the fifth and sixth books. Special effort is made to master a large vocabulary. Five hours a week.

\section{GERMAN.}

German is a required study in the Modern Classical course.

1. Lessons. The First Year in German is devoted to grammar and exercises, to the mastery of a good working vocabulary, of the more important strong and weak verbs, of the common idioms, and to the formation of sentences. Composition and conversation receive close attention. Five hours a week.

2. Reader and Composition. The Senior Year is devoted to easy reading, composition and conversation. Grimm's Fairy Tales, Schiller's Der Neffe als Onkel, Ballads, Wilhelm Tell, indicate the literature read during this year. Five hours a week. 


\section{HISTORY.}

History. The aim of this department is the acquisition by the student of such historical knowledge as will be a necessary element in general culture and a solid foundation for further studies in history. The method of teaching employed is that of the text-book with assigned topics for investigation. The course laid out falls under four heads.

1. English History. Second Year, first semester, three hours a week. The new text-book by Ransome will be used the coming year.

2. Roman History. Second Year, second semester, three hours a week.

3. Greek History. Third year, two periods a week.

4. Modern Fistory. Senior Year, first semester, two hours a week.

\section{NATURAL SCIENCE.}

The Academic or preparatory course in elementary science covers a period of three years, and embraces:

1. Physical Geography, one-half year, three periods a week.

2. Physiology, one-half year, three periods a week.

3. Zoology, one-half year, three periods a week.

4. Botany, one-half year, three periods a week.

5. Chemistry, one-half year, six hours a week.

6. Physics, one-half year, four hours a week. Students of these branches have access to the apparatus and laboratories used in the Collegiate department. 


\section{Business Course.}

FIRST YEAR.

English Grammar, 4.

Arithmetic (1st Sem.) 5.

Commercial Arithmetic, 3.

Physical Geography (2nd

Sem.) 3.

Civics (2nd Sem.) 3.

Penmanship, 4.

Bible (1st Sem.) 2.

JUNIOR YEAR.

Rhetoric, 2.

Algebra (1st Sem.) 4.

Geometry (2nd Sem.) 4.

Commercial Law, 2.

Typewriting, 5 .

Stenography, 4.

Bible, 1.
SECOND Year.

English, 4.

Algebra, 5 .

Bookkeeping, 5 .

Commercial Geography (1st

Sem.) 3.

Business Correspondence, 3 .

Penmanship, 4.

Bible (2nd Sem.) 2.

SENIOR YEAR.

English Literature, 2.

Geometry, 4.

History (Mod.) 2.

Typewriting, 5.

Stenography, 4.

Bible, 1.

We teach a modified system of Graham's Standard Phonography. There are other systems easier to learn, but, so far as demonstrated, there is no system that outranks it in speed, legibility and all-round utility. This system is used by more than fifty per cent. of all court reporters in the United States. Classes in shorthand are organized twice a year, in September, and in January. We do not aim to compete with the "short term" schools, for the average student requires from six to twelve months to reac'i a speed of from one hundred to one hundred twenty-five words a minute in shorthand, new matter, and from thirty-five to forty words a minute on the typewriter on matter transcribed from notes.

Students may enter bookkeeping at any time in the year and the progress depends entirely upon his ability and the time devoted to the study. 


\section{Text-Books.}

English: The Mother Tongue: By Kittridge and Arnold. Rhetoric: Herrick and Damon. English Literature: Painter.

Mathematics: Arithmetic: Packard. Algebra: Wentworth, Olney's Higher. Geometry: Phillips and Fisher.

Latin: Grammar: Harkness. Beginning Book: Smiley and Storke. Prose Conrpositron: Mather and Wheeler. Any standard edition of the authors read.

Greek: Grammar: Hadley-Allen, with Goodwin for reference. Anabasis: Harper and Wallace. Lessons: Boise and Petengill. Prose Composition: Jones.

German: Grammar: Joynes-Meissner. Reader: Joynes. Conposition: Based on text read. Any standard edition of authors read.

History: English: Ransome. Greek: Myers. Others not chosen.

Science: Physical Geography: Tarr. Physiology: Blaisdell. Zoology: Packard. Chemistry: Williams. Priysics: Not chosen. 


\section{Expenses.}

\begin{tabular}{|c|c|c|c|c|c|c|c|}
\hline College- & -Fall term & 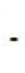 & & & & $\left\{\begin{array}{l}\text { Tuition, } \\
\text { Incidental fee, }\end{array}\right.$ & $\begin{array}{r}\$ 12.00 \\
4.00\end{array}$ \\
\hline "6 & Winter term & - & - & 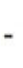 & & $\left\{\begin{array}{l}\text { Tuition, } \\
\text { Incidental fee, }\end{array}\right.$ & $\begin{array}{r}10.00 \\
4.00\end{array}$ \\
\hline " & Spring term & - & - & - & & $\left\{\begin{array}{l}\text { Tuition, } \\
\text { Incidental fee, }\end{array}\right.$ & $\begin{array}{r}10.00 \\
4.00\end{array}$ \\
\hline cadem & -Fall term & - & & & & $\left\{\begin{array}{l}\text { Tuition, } \\
\text { Incidental fee, }\end{array}\right.$ & $\begin{array}{r}10.00 \\
3.00\end{array}$ \\
\hline "، & Winter term & - & - & - & & $\left\{\begin{array}{l}\text { Tuition, } \\
\text { Incidental fee, }\end{array}\right.$ & $\begin{array}{l}8.00 \\
3.00\end{array}$ \\
\hline 66 & Spring term & 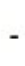 & - & - & & $\left\{\begin{array}{l}\text { Tuition, } \\
\text { Incidental fee, }\end{array}\right.$ & $\begin{array}{l}8.00 \\
3.00\end{array}$ \\
\hline
\end{tabular}

The incidental fee is charged to meet the expense of fuel and repairs, except that $\$ 1.00$ of every incidental fee, each term, is devoted to the gymnasium and to athletic purposes.

Edwards Hall.-Board, including plain

washing, per week, average.....\$2.20 to 2.35

Room rent, per week............ .25

Light and heat, per week, average.... $\quad .20$

Eutrophian Hall.-Board, per week.... 2.30 to 2.50

Room rent, per week............ .25 to .35

Light and heat, per week, average..... $\quad .20$

Plain washing, per week, average..... $\quad .15$

The Elms (Ladies' Hall).-Board per week $\ldots \ldots \ldots \ldots \ldots \ldots \ldots \ldots . .6 \%$

Room rent, per week, including light and heat..................... 
Plain washing, dozen pieces per week. . .25

(Extra washing at special prices.)

Dormitory.-Room rent, with light and steam heat . . . . . . . . .

Corner rooms, each.............

Students rooming in the Dormitory board at Eutrophian or in private families or in Edwards Hall.

Private Families.-Board, per week. . . . 3.00 to 3.50

Room rent, per week.......... .75 to 1.00

Students boarding themselves may reduce the cost somewhat.

Extra Charges-

Analytic Chemistry, for materials used. $\$ 5.00$ to 8.00 Breakage of apparatus in Laboratory. . . Actual Cost

College Diploma.............. $\quad 5.00$

Academic Diploma............ 2.50

Each student in the Dormitory or in Edwards Hall is required to deposit $\$ 2.00$ as a guarantee against damage to college property, and to make it up to that amount at the opening of each term thereafter. From this fund will be deducted (1) charges for repairing for which he is personally responsible; (2) charges (pro rata) for damages done in Dormitory or Hall by unknown hands. The surplus, if any, is refunded to the students at the end of the year, or when they leave the institution. 
Payment of Fees: Tuition and incidental fees must be paid at the beginning of each term in advance.

No deductions are made except for sickness lasting a month or more or in case of those who enter after the middle of the term.

Refunding Tuition: If a student leaves the institution at any time after entrance without the approval of the Faculty or because he has been suspended or dismissed no money will be refunded.

Fees for Partial Students: Students taking seven recitations a week or less will be charged half rates, except that Music students will be permitted to take three recitations a week without extra charge.

Payment of Room Rent: Room rent in the Dormitory and Edwards Flall is paid monthly in advance. Room rent and board in the Elms are paid monthly in advance.

No room rent is charged for the winter or spring vacations unless the rooms are occupied. But, except during these vacations, students are charged for their rooms till they are formally vacated, whether continuously occupied or not.

Half Rates: Sons and daughters of ministers are charged but half the usual rates of tuition. This concession is not limited to Presbyterian ministers.

All candidates for the ministry, of whatever church or denomination, receive tuition at half rates, upon the following conditions: 
(1) Candidates for the Presbyterian ministry shall be under the care of Presbyteries, and shall present to the field secretary or collector certifications to this fact from the clerks of the Presbyteries.

Candidates for the ministry of other denominations shall have their purpose to enter the ministry properly certified to by the proper ecclesiastical authorities.

(2) All such students will be held in honor bound to refund to the College treasury the amount of tuition received in the event of their abandoning their purpose to enter the ministry.

(3) Reduced tuition shall not be provided for any candidate for the ministry who indulges in the use of tobacco.

N. B. The above concession, though made at a great sacrifice to the College, is offered cheerfully and with the purpose of enhancing, as far as possible, the usefulness of the College.

It is, however, justly expected of those who are thus helped that they will be faithful in promoting, as far as in their power, the welfare of the institution; and that they will complete their course of study at this institution.

Special Discount: Where more than one person from the same family attend college at the same time, a discount of twenty-five per cent. will be allowed on the tuition of each person after the first.

High School Scholarships: To the person graduating 
with first honor in any high school, the Board of Trustees will give a scholarship which entitles the holder thereof to free tuition for the ensuing year. To the one graduating with second honor, a half scholarship will be given, which entitles the holder to half tuition for the same time.

The same scholarships are offered those who are graduated from the Academy with first and second honors. This year these scholarships have been awarded to $\mathrm{Mr}$. O. A. Evans, of Minneapolis, and to Miss Ethel C. Brown, of St. Paul.

Furniture: All rooms are furnished with bedsteads (two-thirds size), mattresses, commode, wash-stand, bowl and pitcher, study-table, book-shelves and three chairs. Students must provide their own bed clothing, towels, napkins, lamps, pillows, brooms, and (if they want them) carpets or rugs.

Application: Application for room should be made early to the field secretary, Prof. William J. Johnson, enclosing $\$ 1.00$, which will be applied on room rent. Applicants should state in which hall they desire a room. Rooms will not be held later than the opening of t..e term unless the room rent is advanced for the period of delay.

\section{SUMMARY OF EXPENSES.}

The net expenses for the year, including washing (reckoned at $\$ 18.00$ ), are estimated approximately as follows: 
1. For students paying full tuition:

(1) Rooming in the Dormitory:

(a) Academy ........... $\$ 185.00$

(b) College $\ldots \ldots \ldots \ldots \ldots . \ldots 0.00$

(2) Rooming and boarding in Edwards Hall:

(a) Academy, about.......\$135.00

(b) College, about........ 140.00

2. For those who receive tuition at half rates the above expenses are reduced about $\$ 15.00$.

The above does not include books, traveling expenses, and pin money.

\section{TO PARENTS.}

Parents are earnestly requested (1) to note the rule of the Board requiring the payment of tuition in advanie; (2) to examine carefully the reports of standing sent out at the close of each term; (3) to furnish their sons with but little more money than is needed to meet the necessary expenses as stated above. Students found to be spending money too freely will not be retained in the institution. 


\section{Woman's Auxiliary.}

The Woman's Auxiliary Society was organized some three years ago for the purpose of deepening the interest of the Presbyterian women of Minnesota in Macalester College. It has done a valuable work and deserves hearty support. It seeks to enlist members in all the Presbyterian churches of the State. The membership fee is $\$ 1.00$; honorary membership fee $\$ 10.00$.

Since its organization it has raised over three thousand dollars, which has been carefully expended in repairing and enlarging The Elms. During the past year new rooms have been fitted up and a new heating plant put in at an expense of several hundred dollars.

The officers are:

Mrs. T. D. Simonton (83 Summit Ave.), President.

Mrs. A. E. Brush (Macalester Park), First Vice President.

Mrs. James Compton, Second Vice President.

Mrs. M. D. Edwards, Third Vice President.

Mrs. C. F. Morgan (633 Dayton Ave.) Secretary.

Mrs. R. A. Kirk (15 Laurel Ave., St. Paul), Treasurer.

Mrs. Chas. E. Mackean (399 Ashland Ave.) Corresponding Secretary. 


\section{Roll of Students.}

Senior Class.

William Beckering, a. c...........Leoti, Minn. Louis Benes, a. c................ Firth, Neb. Henry Roy Bitzing, a. c......... St. Paul, Minn. Percy Porter Brush, a. c............Angus, Minn. Belle Irene Campbell, m. c......... St. Paul, Minn. Charles Morrow Farney, a. c.........Elmville, Ont. Henry D. Funk, m. c........... St. Paul, Minn. Nathaniel E. Hoy, m. c........... Winthrop, S. D. Lewis Hughes, a. c.............. Ottawa, Minn. Richard Uriah Jones, a. c........... Ottawa, Minn. William C. Laube, m. c........... St. Paul, Minn. Millicent $\nabla$. Mahlum, a. c..........Brainerd, Minn. William Henry Travis, a. c......... St. Paul, Minn. Lily Bell Watson, a. c.............. Macomb, Ill.

\section{Junior Class.}

Frederick Brown, a. c............ Sylvan, Ont. John Edward Chrystal, a. c........... La Delle, S. D. Sarah A. Haines, m. c............. Austin, Minn. Grace Iddings, m. c.............St. Paul, Minn. Leonard L. Mann, a. c............ Richfield, Minn. F. H. Newton, a. c....Jullundur City, Punjab, India. Winifred Ruth Pringle, a. c.........St. Paul, Minn. Edgar E. Sharp, m. c............ Moorhead, Minn. Benjamin Bruce Wallace, a. c....... St. Paul, Minn. Helen Margaret Wallace, a. c....... St. Paul, Minn. 


\section{Sophomore Class.}

Clarence William Crawford, m. c....Chatfield, Minn. John Morton Davies, a. c........ Courtland, Minn. Harry Garfield Davis, a. c.... . Center Junction, Iowa. William Elliott, p.............. Seaforth, Can. Julia Anita Elmer, a. c........... St. Paul, Minn. Peter Erickson, a. c............. Kasson, Minn. Francis Henry Evans, p......... Minneapolis, Minn. Robert McMaster Hood, a. c...... Island Lake, Minn. Raymond Lewis Kilpatrick, m. c..... . Luverne, Minn. Albert Bruce McCallister, a. c........Madison, S. D. Harry Rhys Morgan, m. c.......... St. Paul, Minn. Phillip Henry Peterson, a. c...... Maple Plain, Minn. Joseph E. Rankin, a. c............ Stephen, Minn. Mary J. Rankin, m. c............. Stephen, Minn. Robert Leslie Thompson, a. c..... Port Colborne, Ont. Pitt Montgomery Walker, a. c..........Macomb, Ill. William Henry Weber, m. c....... Cedar Falls, Wis. Max Millian Wiles, a. c.......... Yorktown, Iowa.

\section{Freshman Class.}

De Loyd Barber, p............... Minneapolis, Minn. Floyd Brown, m. c............ Brainerd, Minn. Peter Arthur Davies, a. c........ Courtland, Minn. Thomas Hunter Dickson, Jr., a. c.... . St. Paul, Minn. Bessie Shepard Doig, m. c........ Claremont, Minn. Lulia Gertrude Douglas, m. c........ Havana, Minn. Margaret Alice Evans, m. c........ Le Sueur, Minn. Walter D. Howell, p............. St. Paul, Minn.

NAMES OMITTED: Sophomore Class.

Peter Westin Jacobson, a. c....... Lanesboro, Minn. Carl William Jensen, p........... Kasson, Minn. 
William H. Kendall, a. c......... Leavenworth, Ind. Alfred Edward Koenig, m. c.... Howard Lake, Minn. Emma Mathilde Larson, m. c........ St. Paul, Minn. George Andrew Nelson, m. c......... Kasson, Minn. William Axel Nord, m. c..........Willmar, Minn. John A. Pritzkau, m. c.......... Bridgewater, S. D. Harry Lawrence Randall, m. c....... Mankato, Minn. Bertha Florence Roddis, m. c........ Leslie, Minn. David Roddis, m. c............... Leslie, Minn. Florence Setzer, p.............. St. Paul, Minn. Ida Grace Sharp, m. c.............. Canton, S. D. George Emil Shellman, a. c...........Amor, Minn. Warren Thomas Stillwell, m. c..... Pipestone, Minn. Henry John Voskuil, m. c.......... Baldwin, Minn. Janet R. Watson, m. c............................... Tolbert Watson, a. c.............. Hoople, N. D. Mabel Wicker, m. c.............. St. Paul, Minn. Laura Woodward, m. c........ Granite Falls, Minn.

\section{MUSIC STUDENTS.}

Minnie Elmira Brandt, p., h......... Murdock, Minn. Cora Bramblett, p................ St. Paul, Minn. Percy Porter Brush, v............... Angus, Minn. Grace I. Chapin, p.............Warren, Minn. John E. Chrystal, v..................... Delle, S. D.

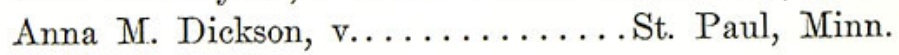
Grace Delameter, p.............. Fulda, Minn. Blanche Firman Coventry, v........ Brainerd, Minn. 
Lovina E. Hansen, p............. Fulda, Minn.

Nathaniel E. Hoy, v., p., h.........Winthrop, S. D.

Lewis Hughes, v., p............. Ottawa, Minn.

Raymond Engene Ingalls, h........ St. Paul, Minn.

Richard Uriah Jones, v............ Ottawa, Minn.

Florence Lucile Johnson, p......... St. Paul, Minn.

Ruth Allyne Johnson, p........... St. Paul, Minn.

Roy Clarke Lammers, $v \ldots . \ldots \ldots$. Stillwater, Minn.

Maroie Leach, p................. Pt. Paul, Minn.

Cathryn Alice McGee, $\mathbf{} \ldots \ldots \ldots \ldots$. . . . Pt. Paul, Minn.

Millicent V. Mahlum, p., h.........Brainerd, Minn.

Leonard E. Mastenbrook, p..........Kasson, Minn. Edith C. Moore, p., v.........Red Lake Falls, Minn. F. H. Newton, v...... Jullunder City, Punjab, India. May De Etta Patterson, p., h... Red Lake Falls, Minn. Grace Taylor, v., viol...............Fulda, Minn. Tolbert A. Watson, p., h...........Hoople, N. D.

\section{ACADEMY.}

\section{Senior Class.}

Sydney Vaughn Ballou............Euclid, Minn. Earl Kenneth Bitzing, m. c......... St. Paul, Minn. Eugene Erwin Bromley, m. c...... Claremont, Minn. Eshel Calvert Brown, m. c.......... St. Paul, Minn. Clyde Reston Chapin, m. c.........Warren, Minn. Grace I. Chapin, m. c...........W Warren, Minn. Mio Genevieve Clark, m. c......... St. Cloud, Minn. Blanche Firman Coventry, p........ Brainerd, Minn. 
Otto Everitt Dornberg, m. c....Redwood Falls, Minn. Isabelle Elmer, m. c............. St. Paul, Minn. Owen Arnold Evans, a. c........Minneapolis, Minn. Thomas Edwin Flinn, m. c.... Redwood Falls, Minn. George Harold Gardner, m. c........ Brainerd, Minn. Ledin Otway Geib, m. c.............. Groton, S. D. Clara Iddings, m. c............. St. Paul, Minn. Elmer Johnson, m. c............ Kimbrae, Minn. Joseph Kubat, m. c........... Montgomery, Minn. Cathryn Alice McGee, m. c......... St. Paul, Minn. Leonard E. Mastenbrook, m. c.........Kasson, Minn. Charles Kivett Morgan, m. c.......Goodhue, Minn. Mav De Etta Patterson, p.... Thief River Falls, Minn.

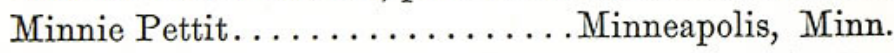
Paul K. Pulte, p.............. Philadelphia, Pa. Carl John Shellman, a. c.............Amor, Minn. Grace Sproat, m. c.............St. Paul, Minn.

\section{Junior and Second Year Classes.}

George Wood Anderson, m. c..........Austin, Minn. Carl Henry Arns................. Bremer, Iowa. James A. Biddeson..........West St. Paul, Minn. Glen Copley Bickley, m. c.......... Kimbrae, Minn. William Herbert Burns, m. c....... St. Paul, Minn. George Cain, m. c............Glenbeulah, Minn. Sarah Canning, m. c........... Hendrum, Minn. Harry Chase Chapin, m. c.......... Euclid, Minn. Julius Thorwald Christensen, m. c. . Elbow Lake, Minn. 
Charles H. Collins.............. Crookston, Minn. Josephine Elmer, a. c............ St. Paul, Minn. Gwilym Humphrey Evans, a. c.... Minneapolis, Minn. Edith Farwell, p............... St. Paul, Minn. Barney Finnson, m. c............. Crystal, N. D. Charles Gillespie, m. c............ Stephen, Minn. James Hamilton, a. c.............. Towner, N. D. Evaline C. Horne............... Harrison, Minn. Jennie Kron, p.............. St. Paul, Minn. Samuel Otto Leslie, p.............Luverne, Minn. Olaf J. Lundell, m. c............. Stillwater, Minn. Allan Lindsay McAfee, m. c......... St. Paul, Minn. Harvey Wells Misner, m. c...........Euclid, Minn. Edith C. Moore, m. c......... Red Lake Falls, Minn. Willie Arthur Murney, m. c.........Euclid, Minn. Richard Samuel Nutt.............. Argyle, Minn. Robert Roy Otis, a. c............. St. Paul, Minn. Percy Roy Pengra, p.............Luverne, Minn. William Fred Pottsmith, p....... Minneapolis, Minn. Charles Richardson, p............Elmore, Minn. George Ritchie................ Duluth, Minn. Philip Setzer, p.............. St. Paul, Minn. John William Stuhr, m. c........... Euclid, Minn. Robert Sinclair Wallace............St. Paul, Minn. Irwin Brown Ward, p...........Minneapolis, Minn. Louie Harris Wilhite, a. c..........Madison, S. D. 


\section{First Year.}

Albin T. Brandt. ............. Murdock, Minn. Elbert Phillips Brush........... St. Paul, Minn. Oliver Hjalmner Hanson. . . . . . . . Stephen, Minn. R. E. Hartzen. . . . . . . . . . . St. Paul, Minn. Fred Sherman Lammers. . . . . . . . . Stillwater, Minn. Roy Clarke Lammers. . . . . . . . . Stillwater, Minn. Arthur John Lundin.............. Stephen, Minn. Robert McConnell.............Fulda, Minn. John McDonald. . . . . . . . . . . Milton, N. D. John Alexander McKenzie..........Vesta, Minn. Otto M. Misz............... St. Paul, Minn. Sidney A. Mosher...........West St. Paul, Minn. Otto Olson.............West Denmark, Wis. John George Richwine........... St. Paul, Minn. Archie Guy Rosaaen............... Fisher, Minn. John Henry Schmaus. ... . . . . . . . St. Paul, Minn. William Stoughton.............. Fisher, Minn. Norman Traviss. . . . . . . . . . . St. Thomas, N. D. Harry Wellington Ward......Redwood Falls, Minn. Anna Bella Watson..........Hendrum, Minn.

\section{Special.}

Harlowe Andrews. . . . . . . . . Two Harbors, Minn. William J. Bates.............. Argyle, Minn. Minnie Almina Brandt...........Murdock, Minn.

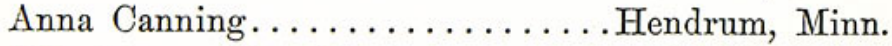
Alice Groves Carmichael...........Fulda, Minn. 
Lovina E. Hansen...............Fulda, Minn. Raymond Eugene Ingalls........... St. Paul, Minn. Vera Pinch............................... Addie Louise Stiles............... Fulda, Minn.

\section{ALUMNI.}

The Alumni organized themselves into an Association in June, 1894. This Association holds its annual business meeting at 4 p. m., and banquet at 5 p. m., on Tuesday preceding commencement, in the President's room. This meeting has become an interesting and important part of the exercises connected with commencement. The purpose of the Association is to cultivate esprit de corps, and to do all in its power to promote the interests of the College.

The officers of the Association are:

Dr. Frank Balcome, Pres.... St. Anthony Park, Minn. Miss Anna M. Dickson, Sec. and Treas. St. Paul, Minn.

Class of 1889.

George Washington Achard.....Lawyer, Minneapolis Jos. Wilson Cochran..........Minister, Philadelphia Ulysses Grant Evans..........Minister, Atkins, Iowa James Chase Hambleton. Teacher, Ancud, Chili, S. A. Benjamin Wallace Irvin............. Deceased Samuel M. Kirkwood...... Surgeon, Hamline, Minn. Wm. Porter Lee.........Minister, Germantown, Pa. Paul Erskine McCurdy... Business, Wilmington, Del. 
Louis Ferdinand Slagle............... Deceased Charles Albert Winter......Lawyer, New York City Class of 1890.

Myron A. Clark. . Sec. Y. M. C. A., Rio Janeiro, Brazil Thaddeus T. Cresswell.........Minister, Beloit, Wis. John Knox Hall...........Missionary, Porto Rico William Henry Humphrey....... Minister, Delhi, O. William Paul Kirkwood..Editor, Minneapolis Journal Amos Avery Randall........ Minister, Marengo, Iowa Judson L. Underwood.........Missionary, Porto Rico Class of 1891.

Frank Brown............ Teacher, Chicago, Ill. Walter F. Finch. . Pastor at large, Fergus Falls, Minn. Walfred Sunberg ................. Deceased William B. Turner..... Teacher, Minneapolis, Minn. Thomas C. Williamson... Business, Greenwood, S. D. Class of 1893.

James Carlisle Simonton... Business, St. Paul, Minn. Joseph Zoll................Minister, Gilman, Ill. Class of 1894.

Francis W. Beidler.......Minister, Jeffersonville, Pa. Archibald Cardle.........Minister, Slayton, Minn. Paul A. Ewert..........Lawyer, Pipestone, Minn. George E. Johnson.......... Minister, El Reno, Ok. Sam'l M. Marsh.........Minister, Sandstone, Minn. Wm. H. Sinclair............Minister, Alden, Minn. Class of 1895.

Frank E. Balcome.Physician, St. Anthony Park, Minn. 
John W. Christianson............Wilmont, Minn. Thomas Fitz-Morris Clark. Minister, Indianapolis, Ind. Chas. D. Darling......... Minister, Petersburg, Ind. Ed. Howard Gordon......... Lawyer, Cavalier, N. D. Harry Clinton Schuler... Missionary, Teheran, Persia. John Hansen Sellie......... Minister, Buffalo, Minn. Nels Sunby, p. c............Minister, Oxford, Neb. Arthur Whitney Vance, Reporter, Daily News, St. Paul Class of 1896.

Winthrop Allison, p. c. Minister, South Omaha, Neb. Alexander Edward Cance. . Supt. Schools, Racine, Wis. Henry A. Leaty, p. c.......... Minister, Mora, Minn. M. M. Maxwell...........Minister, Royalton, Minn. Samuel Feightner Sharp....... Minister, Holly, N. Y. Class of 1897.

Albert Ernest Evans. ......... Student, Chicago, Ill. Charles W. Hansen........ Minister, Romulus, N. Y. Ernest Charles Henke....Minister, Weyawauga, Wis. George Leck........ Missionary, Pyeng Yang, Korea. John McLearie.......... Minister, Rapid City, S. D. Winifred Viola Moore..... Teacher, Virginia, Minn. Arthur A. Palmer.......... Minister, Le Roy, Minn. Charles Petran........Missionary, Saltillo, Mexico Iouis B. Sherwin............ Student, Chicago, Ill. William K. Sherwin....... Student, Rochester, N. Y. Arthur G. Welbon..........Missionary, Seoul, Korea. Class of 1898.

Clarence Dwight Baker. .Teacher, Minneapolis, Minn. 
Charles Warren Dade.........Student, Chicago, Ill. Anna Moore Dickson...... Teacher, St. Paul, Minn. Caspar Gregory Dickson.Clerk Nat. Lib'y, Washington Nellie M. Flanders........ Teacher, Kenyon, Minn. John M. Guise........... Teacher, Kenyon, Minn. Carlton Leslie Koons.......... Student, Chicago, Ill. Robert Charles Mitchell..... Minister, Luzerne, N. Y. William James Mitchell. ... Minister, Pulteney, N. Y. David Walter Morgan..........Student, Chicago, Ill. Class of 1899.

Hugh Stuart Alexander..... Teacher, St. Paul, Minn. Walter Baker Augur.......Student, Princeton, N. J. Charles Allen Clark.......... Student, Chicago, Ill. Ralph Elmo Clark........ Student, Princeton, N. J. Paul Doeltz.............Student, Princeton, N. J. George Clements Edson.... Student, Princeton, N. J. Thomas George Jamieson..... Teacher, Roscoe, S. D. Almira F. Lewis.......... Teacher, St. Paul, Minn. James Murray........... Student, San Anselmo, Cal. Samuel Merton Pinney......Teacher, Blaine, Wash. Jacob Elmer Smits......Teacher, Fairmount, Minn. George Stanley............ Student, Auburn, N. Y. Murray Alberton Travis. . Student, Chicago University Class of 1900 .

John Calvin Abels.... Stated Supply, Brewster, Minn. Mills Strong Grimes........ Student, Princeton, N. J. Ralph Emerson Herron..... Teacher, Paullina, Iowa. John Robert Landsborough. . Student, Princeton, N. J. 
Ernest August Oldenburg... Student, Princeton, N. J. Mathilde Pederson....... Teacher, Albert Lea, Minn. Irving David Roach........ Law Student, California William James Sharp..... Student, San Anselmo, Cal. Ror Walker Smits........Teacher, Brewster, Minn. David Alpheus Thompson. . Student, Princeton, N. J.

Legal Form of Bequest.-I give and bequeath to the Trustees of Macalester College of St. Paul, Minn., duly incorporated under the laws of Minnesota, the sum of 


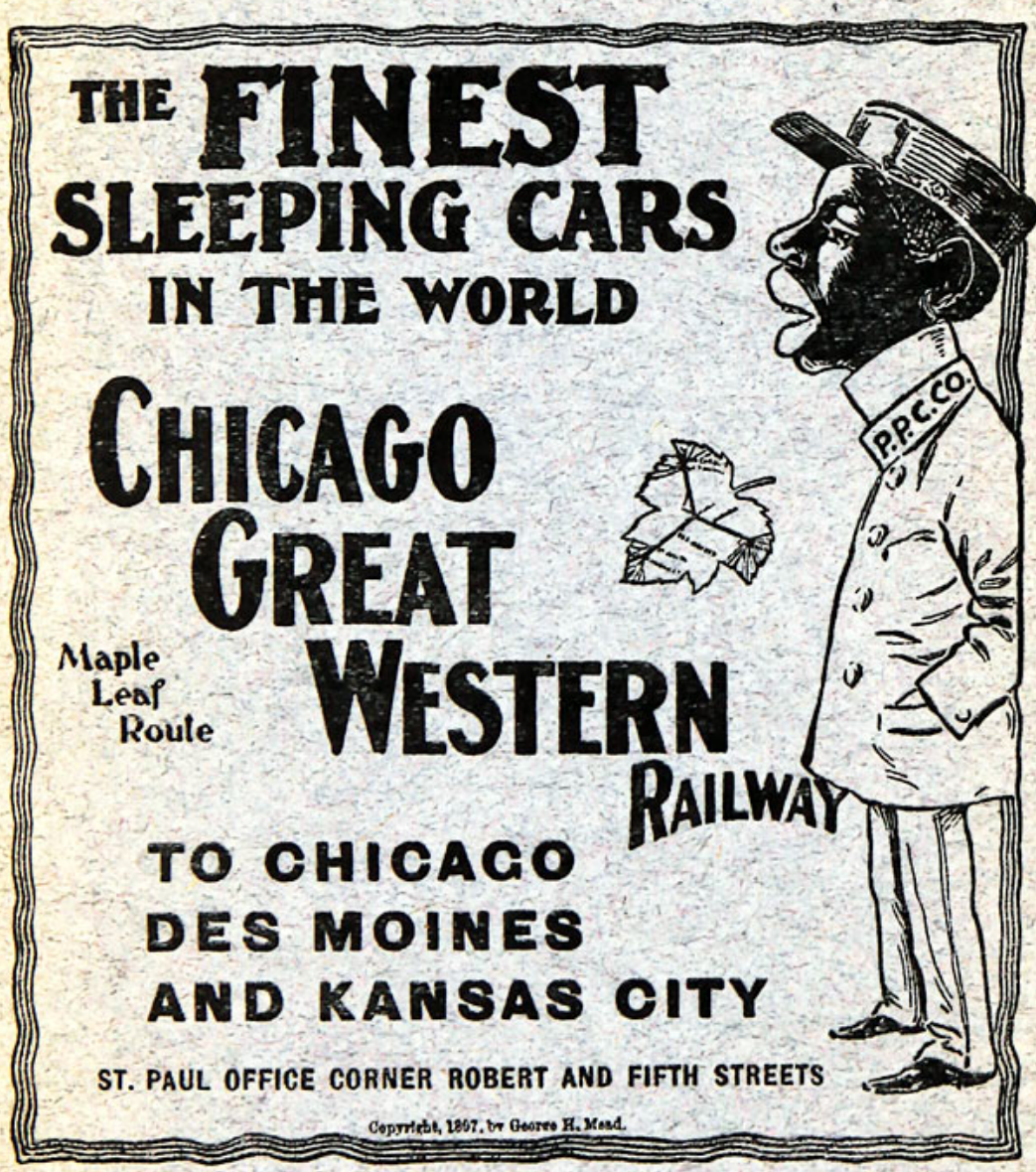




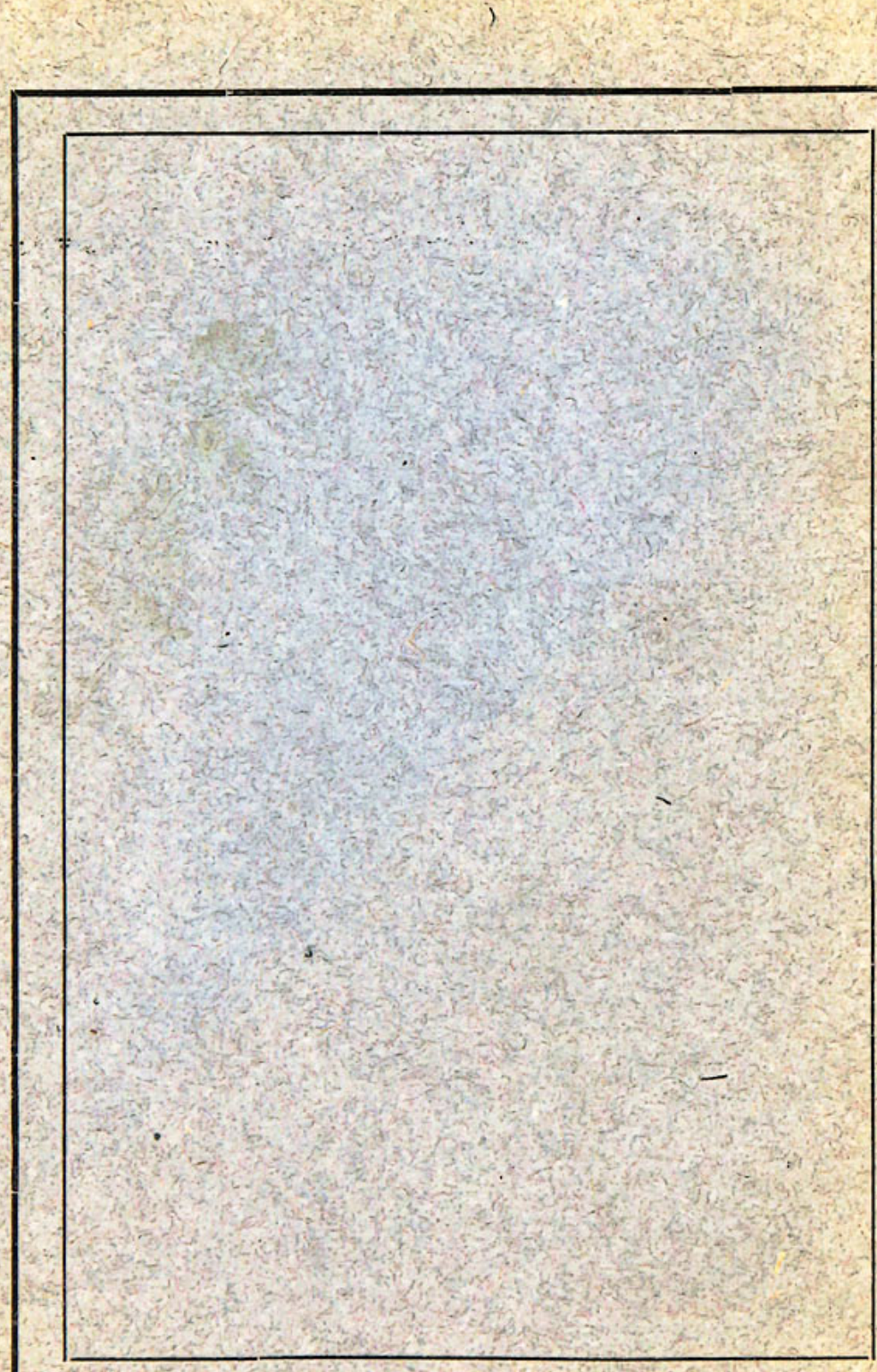

